\title{
1 Prestressed glulam beams reinforced with CFRP bars
}

2 Huifeng Yang ${ }^{*}$, Dongdong Ju, Weiqing Liu, Weidong Lu

\section{ABSTRACT}

This paper describes an experimental test program and theoretical analysis which examines the reinforcing in flexure of glued laminated timber (glulam) beams using bonded-in carbon fiber reinforced polymer (CFRP) bars. A series of four-point bending tests were conducted till failure on unreinforced, passively reinforced and prestressed Douglas fir glulam beams in a simply-supported scheme. The focus of this research was to evaluate the reinforcing efficiency of both passively reinforced and prestressed beams. Test results showed that the flexural capacity of the reinforced, prestressed, prestressed \& reinforced (bottom prestressed and top reinforced) beams greatly increased by $64.8 \%$, $93.3 \%$ and $131 \%$, respectively. While the maximum improvement of the bending stiffness reached $42.0 \%$. Another important finding was that the extreme fiber tensile strain of timber beams at failure could be remarkably increased due to the presence of the tension reinforcement, which indicated it overcomes the effects of local defects and therefore the failure mode was changed from brittle tension failure to ductile compression failure. Based on the experimental results, a theoretical model was proposed to predict the flexural capacity of unreinforced, reinforced and prestressed timber beams, which was validated by the test data.

Key words: Glulam beams; Prestressed; Timber structures; CFRP bars; Four-point bending.

\section{Introduction}

Timber is renewable and sustainable, and it also has the lowest energy consumption and the lowest carbon dioxide emission among many building materials. Thus it is one of the world's most environmentally friendly building materials. Glued laminated timber (glulam), as an engineered wood product, was developed during the $19^{\text {th }}$ century

\footnotetext{
* Corresponding author. Mobile: +86 13913821169; Fax: +86 2558139862.

E-mail address: hfyang@njtech.edu.cn, yhfbloon@163.com (H. Yang)
} 
in Europe and is widely used nowadays in buildings and bridges [1]. Glulam has an excellent strength-to-weight ratio, shape and size flexibility, as well as high strength and dimensional stability.

However, despite all of these benefits, glulam beams are usually underused due to the naturally defects such as knots and cross grain [2]. Another problem is the relative low stiffness as a result of which the design of glulam beams is often controlled by deflection limits [3]. For these reasons, many attempts have been made to reinforce or strengthen glulam or solid timber beams by using high tensile strength materials. In the earlier decades, the majority of this work focused on the use of metallic reinforcement [4-7]. More recently fiber reinforced polymers (FRP) was used as structural reinforcement for timber beams, which in the form of sheets, plates and bars [8-19]. It showed from these researches that the reinforcement in the tension zone would improve the strength, stiffness and ductility. Furthermore, both short-term and long-term deflections of the reinforced timber beams were decreased [3,20].

But the reinforcing materials usually has a notable higher ultimate tensile strain than that of wood, which means it was not effectively used while the failure occurs in this kind of timber members with passive reinforcement. Thus its economic efficiency was argued by some researchers [21,22]. Attempt then was made by introducing prestress in reinforcing materials [2,23-27]. As a result, the flexural strength is further increased due to the full use of both FRP and wood, while bending stiffness is greatly improved because of the pre-camber produced in the flexural members. Also the introduction of prestress may provide an extra strength at a small additional cost [27].

Since there was less research upon prestressed timber beams especially using FRP bars. In this paper, we focus on the improved performance of flexural behavior of glulam beams reinforced with prestressed CFRP bars. Four-point bending tests were conducted on the unreinforced control, passively reinforced and prestressed glulam beams with longitudinally bonded and end anchored CFRP bars. Subsequently a theoretical model was developed, in which the increased tensile strain of glulam timber resulted from reinforcement was taken into consideration. A calibration of the theoretical model was then undertaken based on the experimental results.

\section{Experimental program}

\subsection{Materials}

The glulam beams, CFRP bars and adhesive used in this investigation were purchased from several manufacturers, as detailed below, with the mechanical characteristics either obtained from test results in the university laboratory or furnished by the manufacturers.

\subsubsection{Glulams}

The Douglas fir homogeneous glulam was visually classified by the manufacturer and then tested in the university laboratory according to BS EN13183-1:2002 [28] and BS EN 408:2010 [29]. The characteristic strength properties 


\begin{tabular}{ll}
\hline Specification & Value $\left(\mathrm{N} / \mathrm{mm}^{2}\right)$ \\
\hline Compressive strength & 70.0 \\
Bending strength & 65.0 \\
Splitting strength & 9.2 \\
Modulus of elastic in tension & 3320 \\
\hline
\end{tabular}

(5\% value) directly from test results were shown in Table 1 . And the moisture content of the glulam ranged from $12.9 \%$ to $14.6 \%$ with the mean value of $13.8 \%$, while the density ranged from $461 \mathrm{~kg} / \mathrm{m}^{3}$ to $583 \mathrm{~kg} / \mathrm{m}^{3}$ with the mean value of $531 \mathrm{~kg} / \mathrm{m}^{3}$. The experimental characteristic strength and stiffness properties were compared to those presented by BS EN 1194:1999 [30], which including the grade of GL 28h and GL 36h, as shown in Table 1.

\section{Table 1}

Characteristic strength and stiffness properties of homogeneous glulam.

\begin{tabular}{llll}
\hline Material property & Test results (N/mm $\left.{ }^{2}\right)$ & GL 28h [30] (N/mm $\left.{ }^{2}\right)$ & GL 36h [30] $\left(\mathrm{N} / \mathrm{mm}^{2}\right)$ \\
\hline Tension strength parallel to grain & 32.8 & 19.5 & 26.0 \\
Compression strength parallel to grain & 37.0 & 26.5 & 31.0 \\
Modulus of elasticity parallel to grain, mean value & 12,500 & 12600 & 14700 \\
Modulus of elasticity parallel to grain, 5\% value & 11,400 & 10200 & 11900 \\
\hline
\end{tabular}

\subsubsection{CFRP bars}

The CFRP bars had diameters of $11.0 \mathrm{~mm}$ and $16.0 \mathrm{~mm}$ to obtain two different reinforcement ratios in the tension zone of the glulam. The bars were composed of $65 \%$ unidirectional carbon fiber by volume and $35 \%$ thermoset epoxy resin. The tensile strength of the bars was $2,300 \mathrm{~N} / \mathrm{mm}^{2}$ and modulus of elasticity in tension was 165,000 $\mathrm{N} / \mathrm{mm}^{2}$, as was provided by its manufacturer.

\subsubsection{Adhesive}

A two-component epoxy resin named XK390, with the density of about $1,430 \mathrm{~kg} / \mathrm{m}^{3}$, was used between CFRP bars and glulam beams in this research. The mechanical properties of the adhesive, provided by the manufacturer, are listed in Table 2.

\section{Table 2}

\subsection{Specimens preparation}

Twelve glulam beam specimens were tested to failure under monotonic load in four-point bending configuration. The specimens were $6.0 \mathrm{~m}$ long with a cross section of $75 \mathrm{~mm} \times 300 \mathrm{~mm}$. The reinforced and prestressed specimens were longitudinally slotted at the corresponding face of the CFRP bars (see Fig. 1). The slots were $30 \mathrm{~mm}$ deep and $20 \mathrm{~mm}$ wide for bonded bottom CFRP bars, while $30 \mathrm{~mm}$ deep and $16 \mathrm{~mm}$ wide for bonded top reinforced CFRP bars. The 

beam specimens were then divided into four groups with three replicates for each (see Fig. 1 and Table 3).
81

82 slots were filled with a small timber lamina for all of the specimens with bonded bars after the gluing process. The

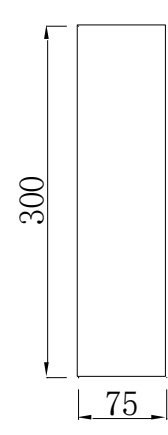

C series

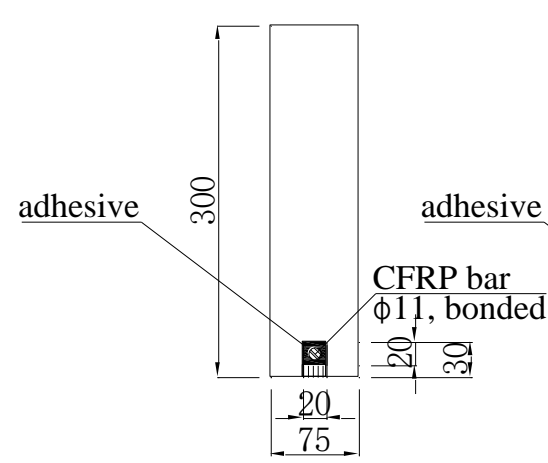

R11 series

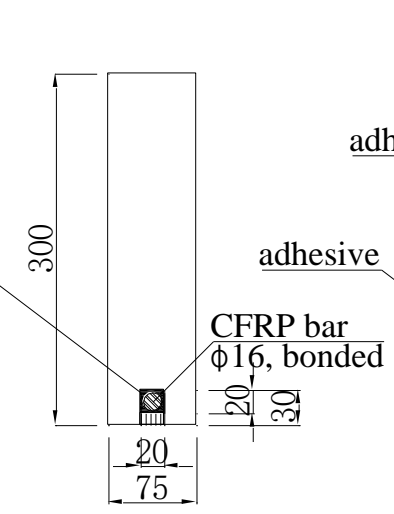

P16 series

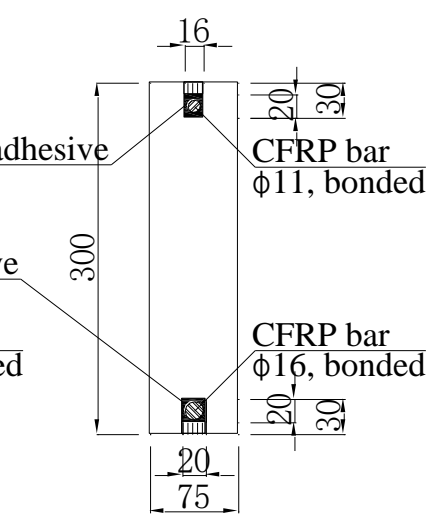

P16R11 series unreinforced control bottom reinforced bottom prestressed bottom prestressed \& top reinforced
Fig. 1. Details of cross section types.

Table 3

Series and specimen information.

\begin{tabular}{|c|c|c|c|c|c|c|c|}
\hline \multirow{2}{*}{$\begin{array}{l}\text { Series } \\
\text { reference }\end{array}$} & \multirow{2}{*}{$\begin{array}{l}\text { No. of } \\
\text { replicates }\end{array}$} & \multicolumn{6}{|l|}{ Reinforcement } \\
\hline & & Type & Location & $\begin{array}{l}\text { Diameter } \\
(\mathrm{mm})\end{array}$ & Anchorage type & $\begin{array}{l}\text { Cross-section } \\
\text { ratio }(\%)\end{array}$ & $\begin{array}{c}\text { Prestress force } \\
(\mathrm{kN})\end{array}$ \\
\hline $\mathrm{C}$ & 3 & - & - & - & - & 0.00 & - \\
\hline R11 & 3 & $\begin{array}{c}\text { passive } \\
\text { reinforcement }\end{array}$ & Bottom & 11 & $\begin{array}{l}\text { End anchor and } \\
\text { bonded }\end{array}$ & 0.42 & 0.0 \\
\hline $\mathrm{P} 16$ & 3 & prestressed & Bottom & 16 & $\begin{array}{l}\text { End anchor and } \\
\text { bonded }\end{array}$ & 0.89 & 50.8 \\
\hline P16R11 & 3 & $\begin{array}{l}\text { prestressed and } \\
\text { reinforcement }\end{array}$ & Bottom and top & $\begin{array}{c}16 \text { and } \\
11^{\mathrm{a}}\end{array}$ & $\begin{array}{l}\text { End anchor and } \\
\text { bonded }\end{array}$ & 0.89 and $0.42^{b}$ & 50.8 \\
\hline
\end{tabular}

${ }^{\mathrm{a}}$ Bottom prestressed bar was $16 \mathrm{~mm}$ in diameter and top reinforced bar was $11 \mathrm{~mm}$ in diameter.

${ }^{\mathrm{b}}$ Cross-section ratio for bottom prestressed bar was 0.89 and for top reinforced bar was 0.42 .

${ }^{\mathrm{c}}$ Prestress force was average strain values of the CFRP bars at mid-point of the three glulam beams in each series.

Prior to the bonding operation, the glulam slots were cleaned with high-pressure air while the CFRP bars were cleaned with acetone. The prestress was produced by the Preflex process [31], as shown in Fig. 2, through the symmetrical four-point bending loads. The end anchorages were tightened then as the glulam beam deformation came to the predicted value. Furthermore, the CFRP bar could be re-tightened if necessary by the nuts of the straight sleeve bonded-type anchorages (see Fig. 3). And a detailed description and comprehensive review of these kind of anchorages without nuts can also be found in the literature [32]. Subsequently, the slots were filled with the adhesive for the reinforcement/prestressed glulam specimens. The preflexion loads remained constant for about 72 hours at the environmental temperature of $20 \pm 2^{\circ} \mathrm{C}$. And then the applied Preflex load were slowly released while the concerned 
strains and deflections, including pre-camber, were recorded. The prestress force was then calculated from the average strain values of the CFRP bars at mid-point of the glulam beams and presented in Table 3 . The glulam beam was immediately overturned and tested to failure, which presents a detailed report in the following part of this paper.

(a)
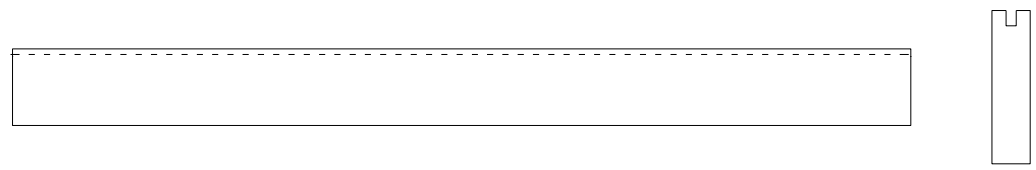

(b)

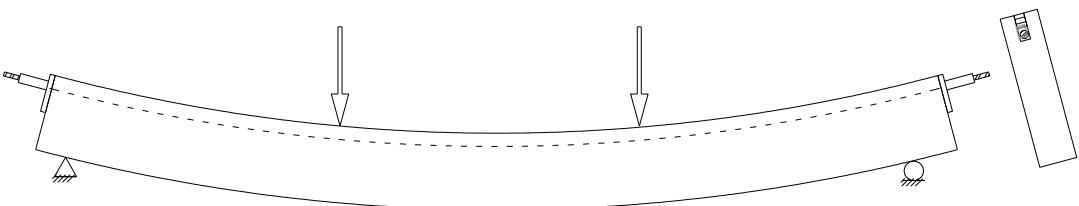

(c)

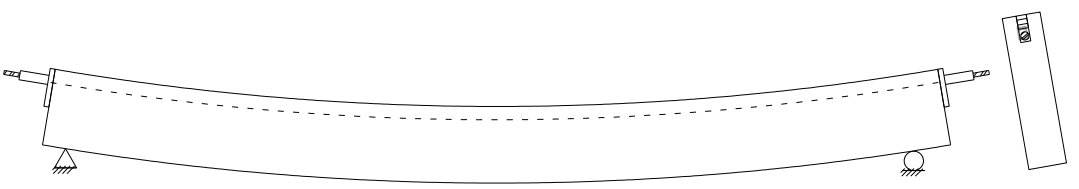

(d)

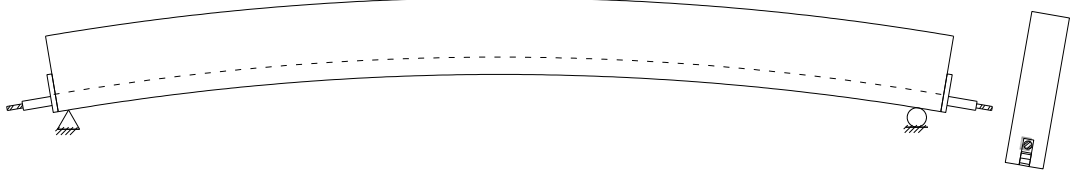

Fig. 2. Phases of construction of prestressed beam: (a) assemblage of glulam beam, (b) pre-deflection of glulam beam and filling the slots with adhesive, (c) release of glulam beam after the adhesive is well cured and (d) Overturn of glulam beam and prepare to test.

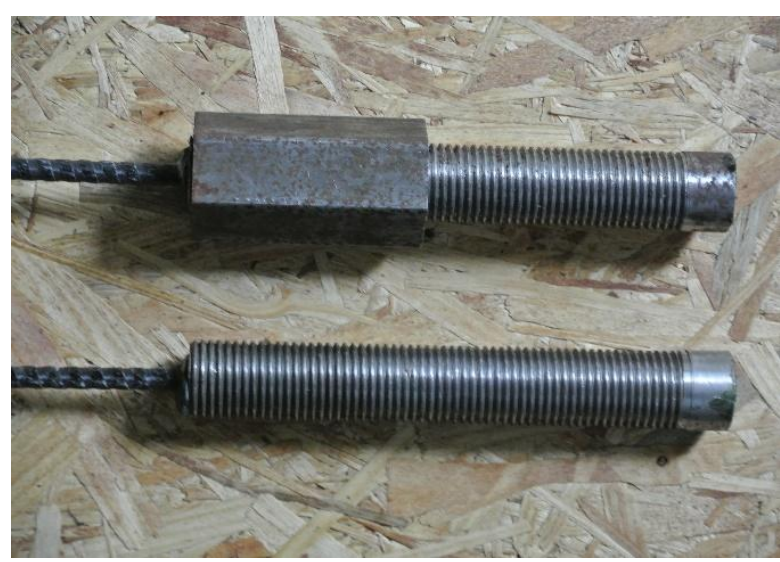

Fig. 3. Straight sleeve anchorages with nuts.

According to Negrão [27], during specimen preparation and test procedure, the possible prestress loss mainly caused by the contact condition of the anchor nuts and the elastic recovery of the specimens. However, the tensile strain of the prestressing FRP bars has been recording during this stage so that the prestress force is known to us. Also Negrão [27] discussed the prestress loss under long-term condition and pointed out that creep and reinforcement relaxation is one of the most concerning aspects. However, the issue on prestress loss is not the focus of this research. 


\subsection{Flexural test procedure and beam instrumentation}

113

All glulam beam specimens were tested using the four-point bending method in accordance to BS EN 408:2010 [29], with the test setup as shown in Fig. 4. The loading rate was set to $5.0 \mathrm{~mm} / \mathrm{min}$ and was held constant until failure. Lateral roller-type restraint was provided to prevent buckling or lateral torsional effects. Since the mid-span deflection is a relative value about that of supports, linear variable differential transformers (LVDTs) were located at both midpoint and end supports of the glulam beam, while strains were monitored by paper based strain gauge at mid-span of the beam both throughout the depth with a space of $75 \mathrm{~mm}$ and in CFRP bars. It should be noted that strain gauges just included on one side of glulam beams, so the twist of beams and deviations of wood quality were not accounted for.

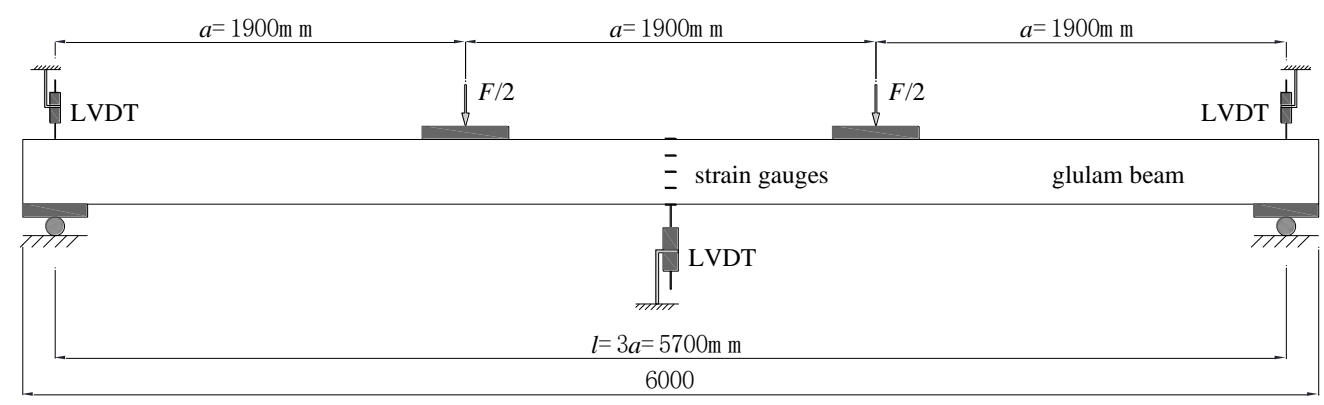

Fig. 4. Test set-up and arrangement.

\subsection{Experimental results \& discussion}

\subsubsection{Load-deflection behavior}

Figs. 5-8 represents the load-deflection behaviour of the four series of glulam beams including unreinforced, reinforced and prestressed:

- The load-deflection behaviour of the unreinforced control beams (C-1, C-2 and C-3) are shown in Fig. 5. All the glulam beams exhibited linear elastic behaviour till the failure at tension face due to the presence of either knots or cross grain. No compression yielding occurred in the compression zone of the glulam beams.

- As can be seen from the load-deflection curves of the bottom reinforced beams (R11-1, R11-2 and R11-3) shown in Fig. 6, non-linear behaviour is introduced into the beams before the maximum load was reached. This means that the yielding of the wood in the compression zone occurred before the wood of tension face reached the ultimate tensile strain.

- Fig. 7 plots the load-deflection curves of the two bottom prestressed beams (P16-1 and P16-2). The bottom prestressed beams shows almost the same load-deflection behaviour as that of bottom reinforced beams. Furthermore, the deflection of the prestressed beam decreased, when compared to the reinforced beams, due to the 
pre-camber produce by the prestress. The load-deflection data of the specimen P16-3 was not recorded because of the faulty LVDT.

- Fig. 8 illustrates the load-deflection curves of the bottom prestressed \& top reinforced beams (P16R11-1, P16R11-2 and P16R11-3). Due to the presence of the top reinforcement in the compression zone, as can be seen from Fig. 8, it shows less non-linear behaviour than that of just prestressed beams. It indicates that the compression reinforcement suspend or prevent the wood yielding in the compression zone. And as a result, the ultimate load of this series is even higher.

It should be noted that the post failure behaviour of most reinforced or prestressed beams was not recorded during the test. So it is not possible to predict the ductility of the tested beams.

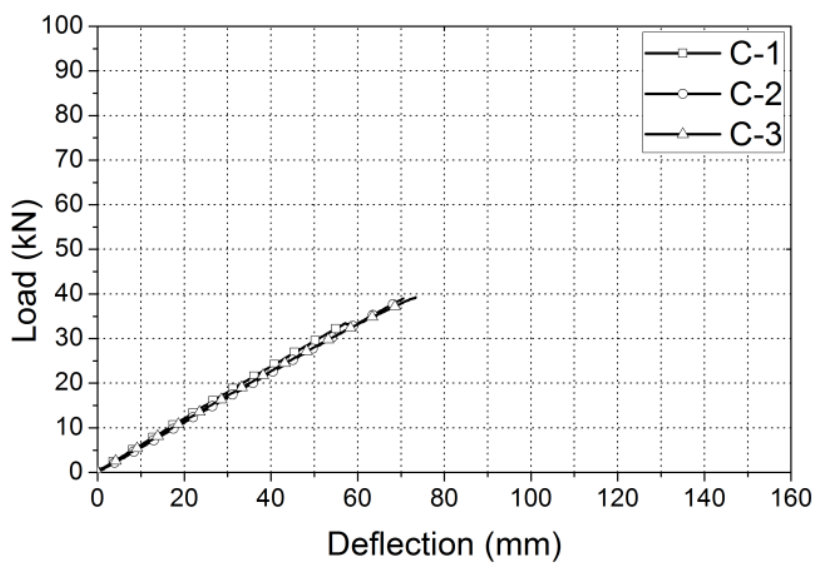

Fig. 5. Load-deflection curve for the unreinforced control beams (C series).

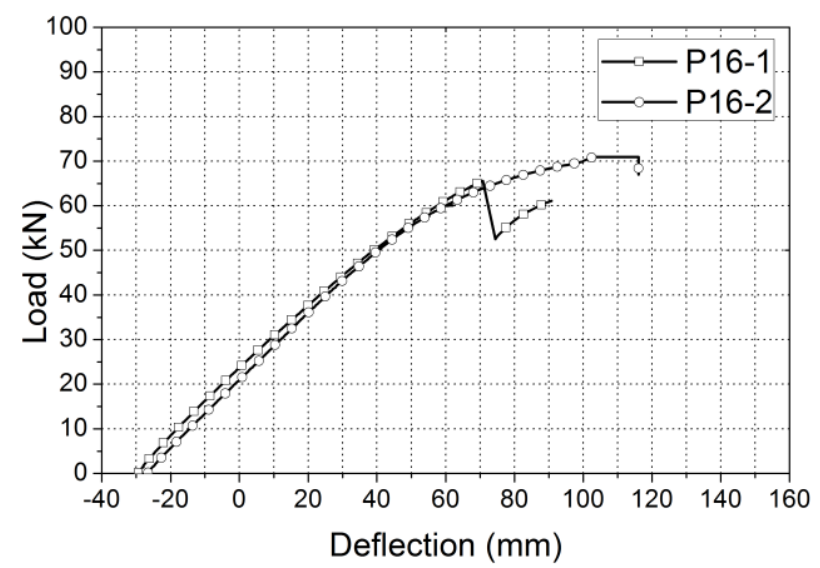

Fig. 7. Load-deflection curve for the bottom prestressed beams (P16 series).

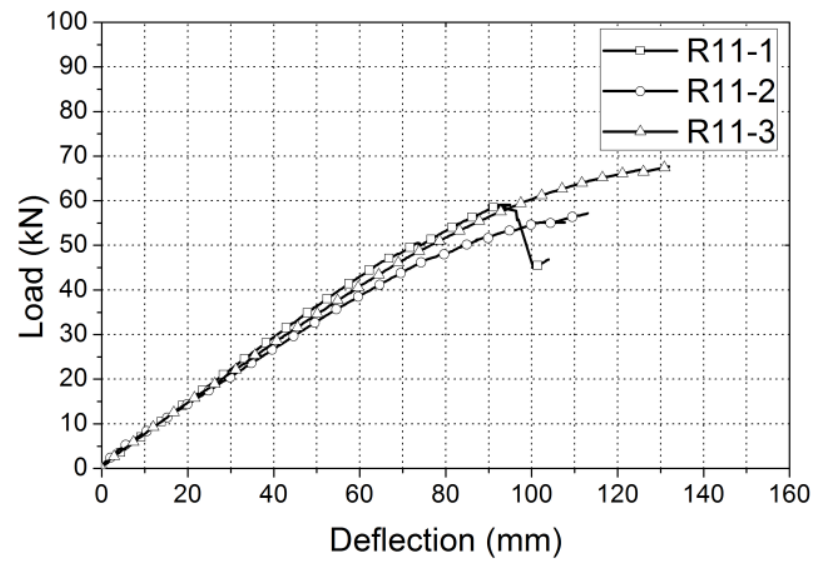

Fig. 6. Load-deflection curve for the bottom reinforced beams (R11 series).

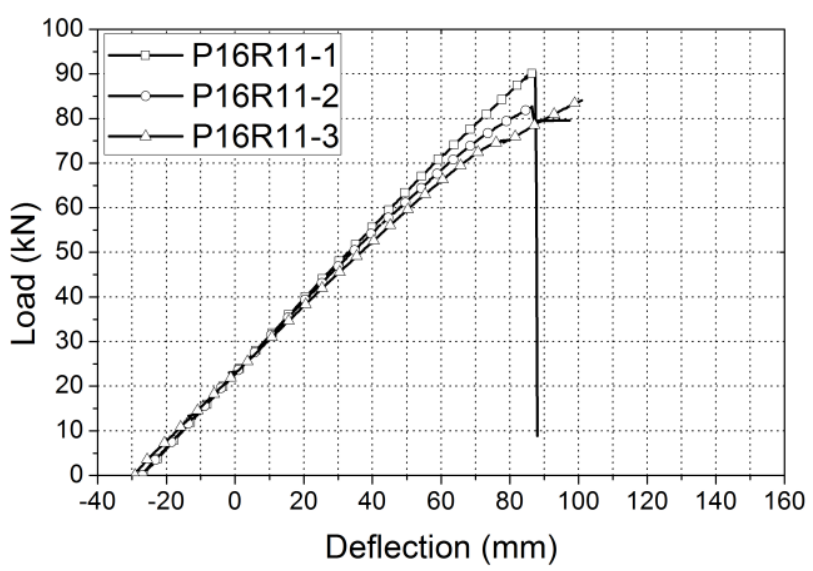

Fig. 8. Load-deflection curve for the bottom prestressed \& top reinforced beams (P16R11 series).

The test results are also summarized in Table 4. It can be seen from Table 4 that the failure load was significantly improved for either reinforced or prestressed glulam beams. These improvements reached $64.8 \%, 93.3 \%$ and $131 \%$ 
for the passive reinforced, prestressed and prestressed \& reinforced glulam beams, respectively. The average failure

155

\begin{tabular}{|c|c|c|c|c|c|c|}
\hline Specimen type & Beam code & $\begin{array}{l}\text { Failure } \\
\text { load } \\
F_{\mathrm{u}}(\mathrm{kN}) \\
\end{array}$ & $\begin{array}{l}\text { Failure } \\
\text { moment } M_{\mathrm{u}} \\
(\mathrm{kNm})\end{array}$ & $\begin{array}{l}\text { Load at the mid-span } \\
\text { deflection reached } \\
L / 250 F_{\mathrm{L} / 250}(\mathrm{kN})\end{array}$ & $\begin{array}{l}\text { Stiffness } \\
E_{\mathrm{mg}} I \\
\left(10^{12} \mathrm{Nmm}^{2}\right) \\
\end{array}$ & Failure modes \\
\hline \multirow{5}{*}{$\begin{array}{l}\text { Unreinforced } \\
\text { control beam } \\
\text { (C series) }\end{array}$} & $\mathrm{C}-1$ & 33.5 & 31.8 & 13.7 & 2.03 & Tension \\
\hline & $\mathrm{C}-2$ & 39.0 & 37.1 & 12.7 & 1.91 & Tension \\
\hline & C-3 & 39.3 & 37.1 & 13.1 & 1.94 & Tension \\
\hline & Average & 37.3 & 35.3 & 13.2 & 1.96 & - \\
\hline & $\begin{array}{l}\text { Standard } \\
\text { deviation }\end{array}$ & 3.3 & 3.0 & 0.50 & 0.06 & - \\
\hline \multirow{6}{*}{$\begin{array}{l}\text { Reinforced beam } \\
\text { (R11 series) }\end{array}$} & R11-1 & 59.1 & 56.1 & 17.0 & 2.52 & Compression \\
\hline & R11-2 & 57.3 & 54.4 & 16.1 & 2.13 & Compression \\
\hline & R11-3 & 67.7 & 64.3 & 16.7 & 2.33 & Compression \\
\hline & Average & 61.3 & 58.3 & 16.6 & 2.33 & - \\
\hline & $\begin{array}{l}\text { Standard } \\
\text { deviation }\end{array}$ & 5.6 & 5.3 & 0.46 & 0.18 & - \\
\hline & $\%$ increase $^{a}$ & 64.8 & 64.8 & 26.1 & 18.9 & - \\
\hline \multirow{6}{*}{$\begin{array}{l}\text { Prestressed beam } \\
\text { (P16 series) }\end{array}$} & P16-1 & 65.6 & 62.3 & 39.7 & 2.62 & Compression \\
\hline & P16-2 & 70.9 & 67.4 & 38.0 & 2.61 & Compression \\
\hline & $\mathrm{P} 16-3^{\mathrm{b}}$ & 79.2 & 75.2 & - & - & Compression \\
\hline & Average & 71.9 & 68.3 & 38.9 & 2.61 & - \\
\hline & $\begin{array}{l}\text { Standard } \\
\text { deviation }\end{array}$ & 6.9 & 6.5 & 1.20 & 0.01 & - \\
\hline & $\%$ increase $^{a}$ & 93.3 & 93.3 & 195.1 & 33.2 & - \\
\hline \multirow{6}{*}{$\begin{array}{l}\text { Prestressed \& } \\
\text { reinforced beam } \\
\text { (P16R11 series) }\end{array}$} & P16R11-1 & 90.6 & 86.1 & 41.8 & 2.91 & Flexure-shear \\
\hline & P16R11-2 & 82.7 & 78.6 & 41.2 & 2.84 & Flexure-shear \\
\hline & P16R11-3 & 84.2 & 80.0 & 40.0 & 2.61 & Flexure-shear \\
\hline & Average & 85.9 & 81.5 & 41.0 & 2.79 & - \\
\hline & $\begin{array}{l}\text { Standard } \\
\text { deviation }\end{array}$ & 4.2 & 4.0 & 0.92 & 0.14 & - \\
\hline & $\%$ increase $^{a}$ & 131 & 131 & 211.4 & 42.3 & - \\
\hline
\end{tabular}

${ }^{\mathrm{a}}$ Improvement compared to the unreinforced control beam in average value.

\footnotetext{
${ }^{\mathrm{b}}$ The deflection and stiffness values are not available due to the faulty LVDT.
} 
It also can be seen from Table 4 that, as compared to the unreinforced control beams, the beam stiffness $\left(E_{\mathrm{mg}} I\right.$, calculated using Eq. (1) shown below, which was derived from BS EN 408: 2010 [29]) increased by 18.9\%, 33.2\% and $42.3 \%$ for the passive reinforced, prestressed, and prestressed \& reinforced glulam beams, respectively.

$E_{m g} I=\frac{3 a l^{2}-4 a^{3}}{24\left(\frac{2\left(w_{2}-w_{1}\right)}{F_{2}-F_{1}}-\frac{6 a}{5 G b h}\right)}$

Where $E_{\mathrm{mg}}(\mathrm{MPa})$ : global modulus of elasticity; $I\left(\mathrm{~mm}^{4}\right)$ : the section moment of inertia; $a(\mathrm{~mm})$ : distance to loading point (see Fig. 4); $l(\mathrm{~mm})$ : beam span (see Fig. 4); $w_{1}(\mathrm{~mm})$ : deformation at $F_{1} ; w_{2}(\mathrm{~mm})$ : deformation at $F_{2} ; F_{1}(\mathrm{~N})$ : applied load at $10 \%$ of estimated maximum load: $F_{2}(\mathrm{~N})$ : applied load at $40 \%$ of estimated maximum load; $G(\mathrm{MPa})$ : shear modulus ( $\mathrm{G}=850 \mathrm{MPa}$ for glulam with the grade of GL28h according to BS EN 1194:1999 [30]); $b$ (mm): beam width; $h(\mathrm{~mm})$ : beam depth.

\subsubsection{Failure modes}

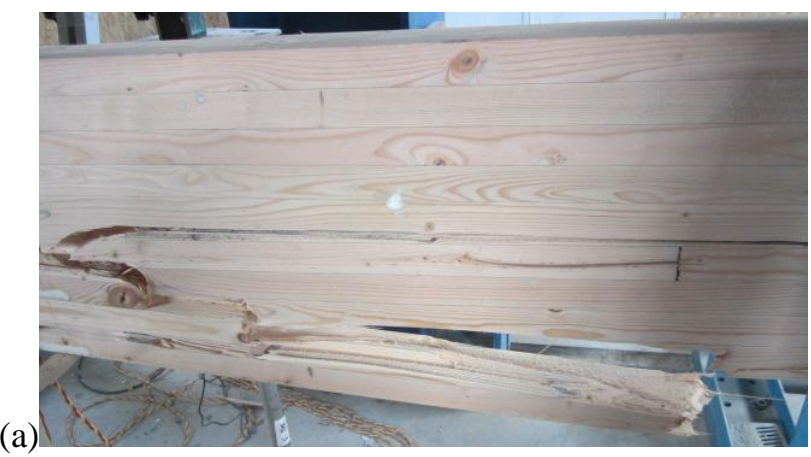

(b)

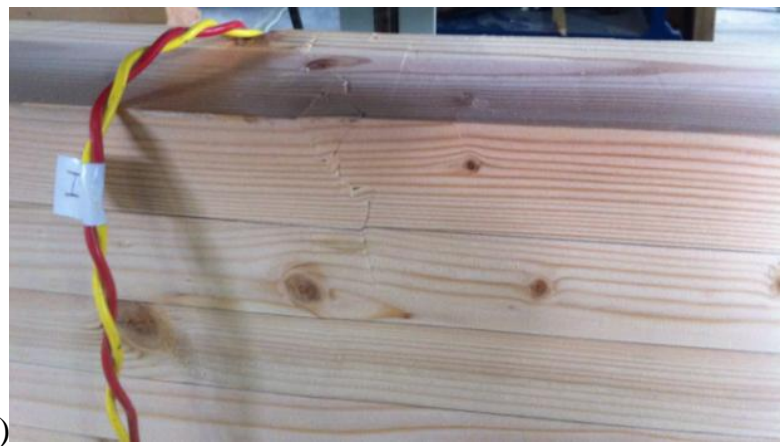

(c)

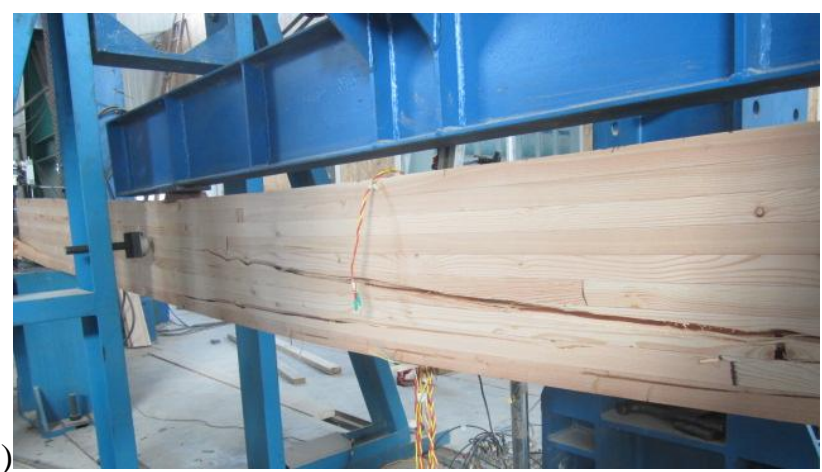

Fig. 9. Typical failure modes of the beams: (a) tension failure, (b) compression failure and (c) flexure-shear failure.

Out of the 4 series of beams tested, the unreinforced control beams all failed in tension mode at the location of natural defects (C series, see Fig. 9(a)), 2 series failed in compression mode (R11 series and P16 series, see Fig. 9(b)), while the series of prestressed \& reinforced beams all failed in combined flexure and shear mode (P16R11 series, see Fig. 9(c)), as summarized in Table 4. The introduction of the CFRP bars caused a change in the failure mode from brittle tension in the unreinforced beams to a ductile compression failure, which is a common phenomenon for the reinforced/prestressed timber beams reported by many authors $[11,13,16,17,19,36]$. There was no rupture of the 
CFRP bars due to their high strength. As a result of the addition of the end anchorage as well as the longitudinal bonding of CFRP bars, none of the failures were due to debonding.

\subsubsection{Strain distribution}

Typical load-strain curves are illustrated in Figs. 10-13. It can be seen from the figures that the load-strain curve for the unreinforced beams (see Fig. 10) remained nearly linear, while the reinforced and prestressed ones showed a non-linear behaviour at the late stage of the curves, as a result of the wood crushing in the compression zone (see Fig. 11 and Fig. 12). For prestressed \& reinforced glulam beams, there was less non-linear behaviour due to the reinforcement in compression zone, which could reduce the compressive strain of the wood (see Fig. 13).

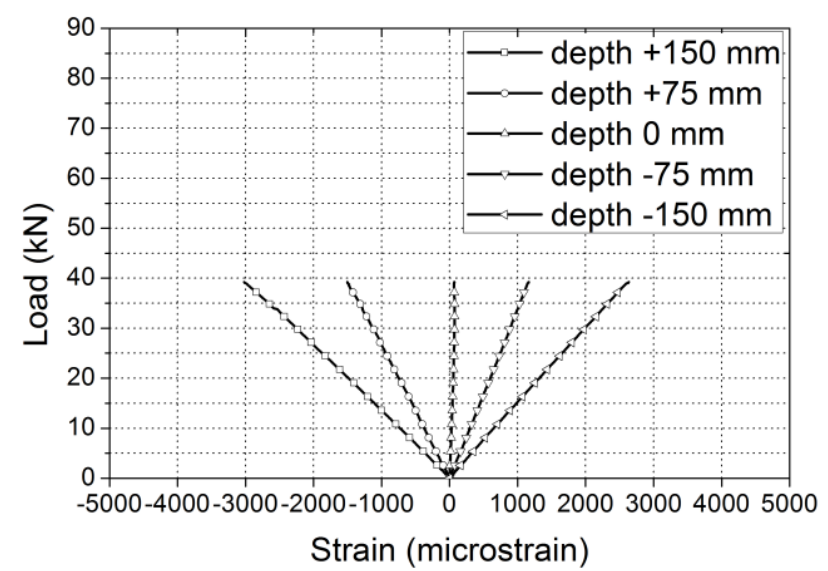

Fig. 10. Typical load-strain curve for an unreinforced reinforced control beam (C-3).

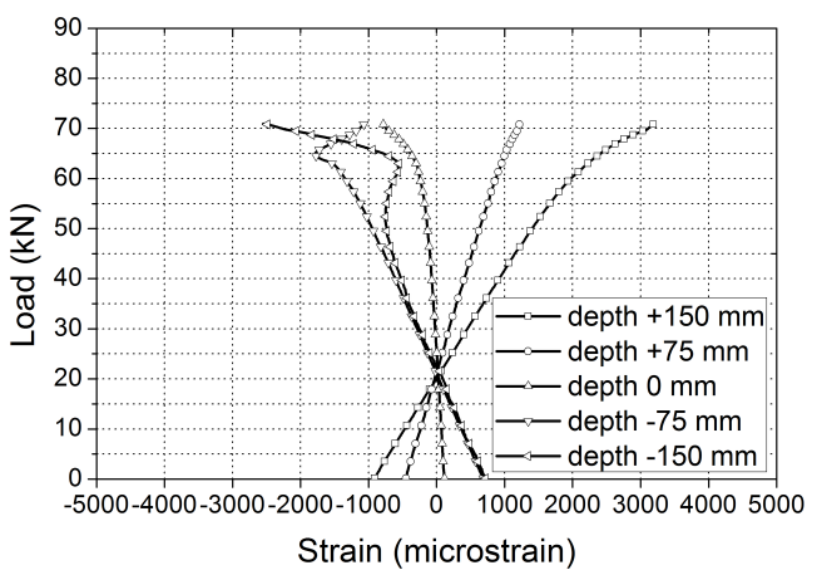

Fig. 12. Typical load-strain curve for a bottom prestressed beam $(\mathrm{P} 16-2)$.

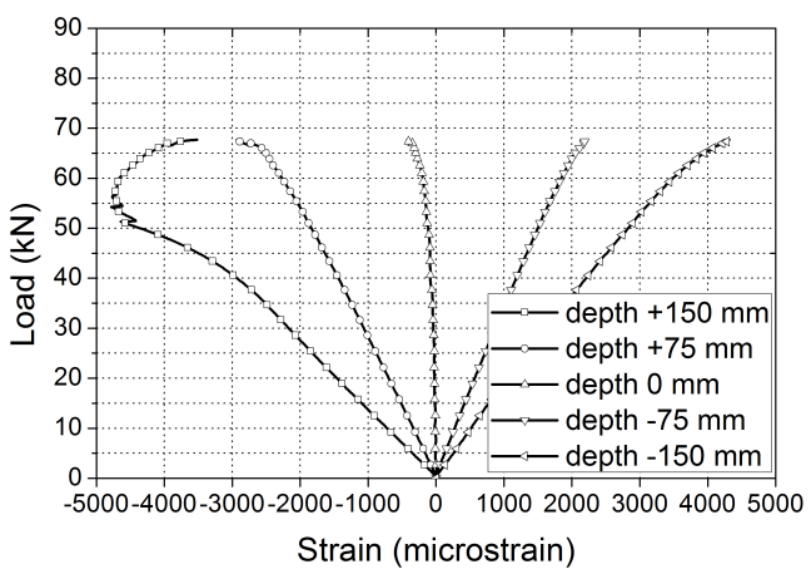

Fig. 11. Typical load-strain curve for a bottom beam $(\mathrm{R} 11-3)$.

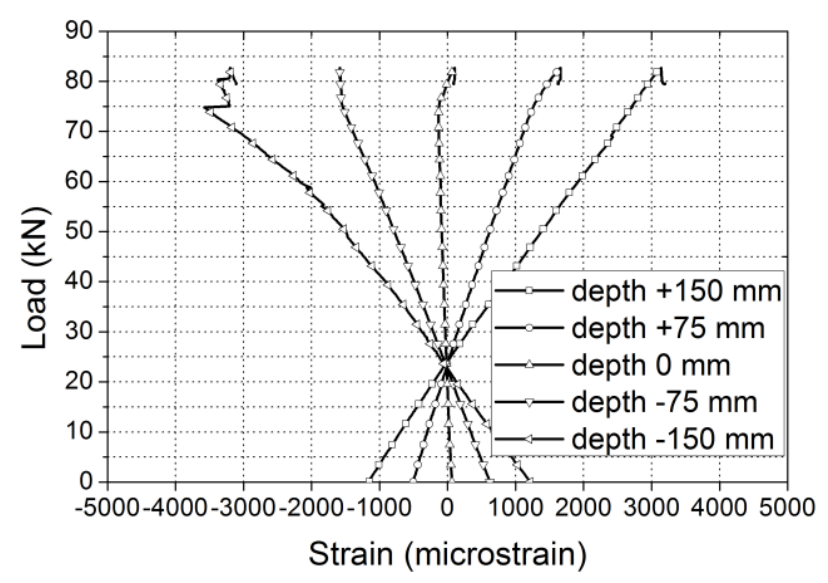

Fig. 13. Typical load-strain curve for a bottom prestressed \& top reinforced beam (P16R11-2).

Figs. 14-17 plot the strain profiles at mid-span for typical specimens of the four series under different load levels till failure. As the load increases to failure, the mechanical neutral axis position moves from $-4.4 \mathrm{~mm}$ to $-8.7 \mathrm{~mm}$ against the geometric neutral axis for unreinforced beams (see Fig. 14), while from $-4.4 \mathrm{~mm}$ to $-12.1 \mathrm{~mm}$ for passively 


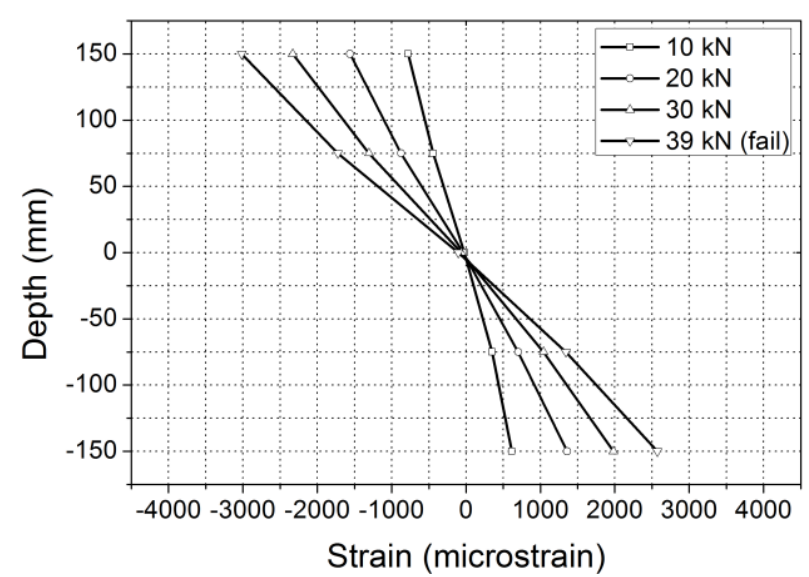

Fig. 14. Typical strain profile for an unreinforced beam (P16-2).

Fig. 16. Typical strain profile for a bottom prestressed of strain values to the compression face.

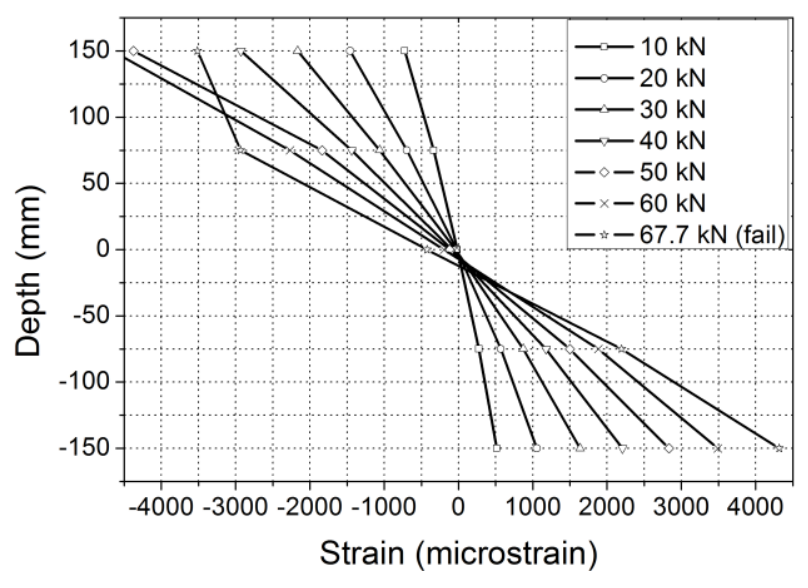

Fig. 15. Typical strain profile for a bottom reinforced beam (R11-3).

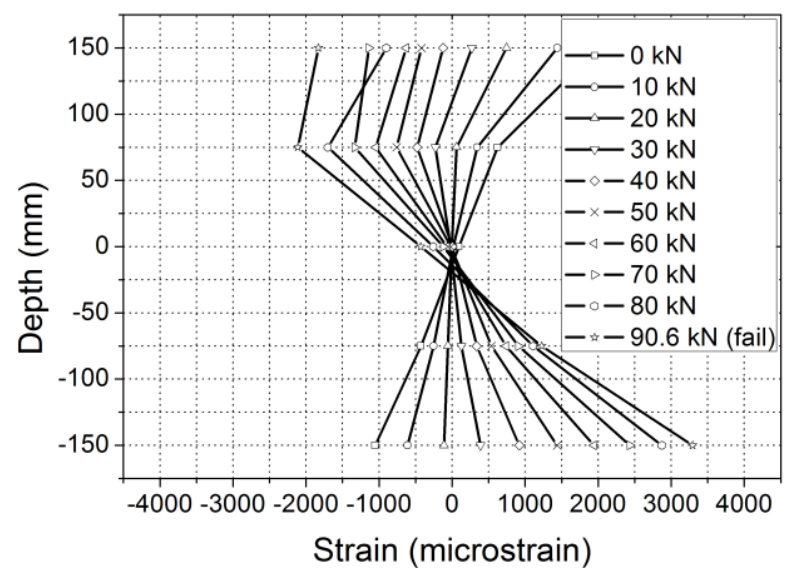

Fig. 17. Typical strain profile for a bottom prestressed \& top reinforced beam (P16R11-3).

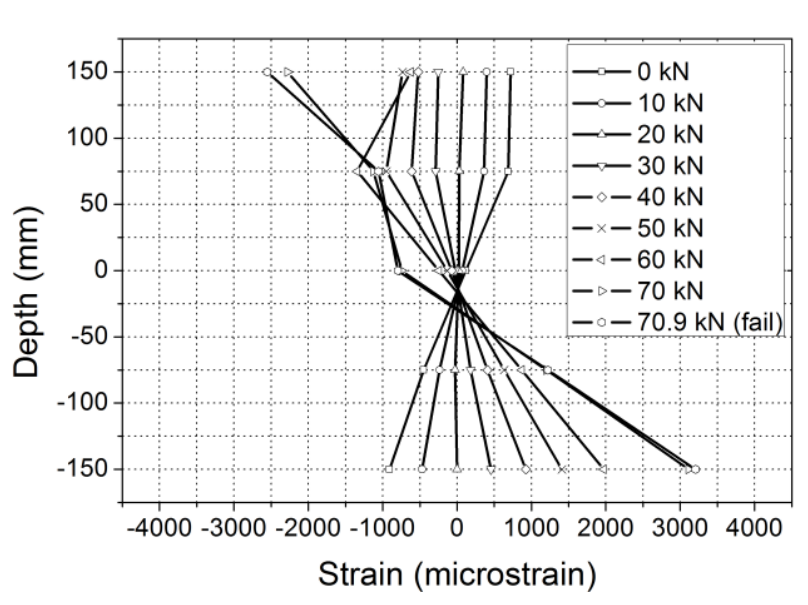
The average extreme fibre strain for both compressive and tensile at failure is summarized in Table 5. As can be seen from Table 5, both the average extreme fiber tensile and compressive strain at failure were all about $0.25 \%$ for the unreinforced beams. The introduction of the reinforcement or prestress could maximally increase the average extreme fibre tensile and compressive strain by $77.6 \%$ (with a tensile strain value of about $0.44 \%$ ) and $88.2 \%$ (with a compressive strain value of about $0.47 \%$, respectively. This finding is consistent with many studies [11,33-36].

Since the strain gauges could not record the exact global compressive strain of wood in the late loading stage, the extreme fiber compressive strain (as listed in Table 5) was then estimated from the strain values at the beam height of $0 \mathrm{~mm}$ and $75 \mathrm{~mm}$ (or $0 \mathrm{~mm}$ and $-75 \mathrm{~mm}$ for specimen P16-2), by extending the straight line between these two points 
219 Comparison of extreme fibre strain at failure of the specimens.

\begin{tabular}{|c|c|c|c|}
\hline Specimen type & Beam code & $\begin{array}{l}\text { Extreme fiber compressive strain } \\
\varepsilon_{\mathrm{c}, \max }(\text { microstrain })\end{array}$ & $\begin{array}{l}\text { Extreme fiber tensile strain } \\
\varepsilon_{\mathrm{t}, \max }(\text { microstrain })\end{array}$ \\
\hline \multirow{5}{*}{$\begin{array}{l}\text { Unreinforced control beam } \\
\text { (C series) }\end{array}$} & C-1 & -2758 & 2288 \\
\hline & $\mathrm{C}-2$ & -1724 & 2572 \\
\hline & $\mathrm{C}-3$ & -3025 & 2638 \\
\hline & Average & -2502 & 2499 \\
\hline & Standard deviation & 687 & 186 \\
\hline \multirow{6}{*}{$\begin{array}{l}\text { Reinforced beam } \\
\text { (R11 series) }\end{array}$} & $\mathrm{R} 11-1$ & -4110 & 4450 \\
\hline & $\mathrm{R} 11-2$ & -4120 & 4550 \\
\hline & R11-3 & -5500 & 4317 \\
\hline & Average & -4577 & 4439 \\
\hline & Standard deviation & 800 & 117 \\
\hline & $\%$ increase $^{a}$ & 82.9 & 77.6 \\
\hline \multirow{6}{*}{$\begin{array}{l}\text { Prestressed beam } \\
\text { (P16 series) }\end{array}$} & P16-1 & -5625 & 3300 \\
\hline & $\mathrm{P} 16-2$ & -3810 & 2820 \\
\hline & P16-3 & -4690 & 3200 \\
\hline & Average & -4708 & 3107 \\
\hline & Standard deviation & 908 & 253 \\
\hline & $\%$ increase $^{a}$ & 88.2 & 24.3 \\
\hline \multirow{6}{*}{$\begin{array}{l}\text { Prestressed \& reinforced beam } \\
\text { (P16R11 series) }\end{array}$} & P16R11-1 & -3541 & 3871 \\
\hline & P16R11-2 & -3199 & 3143 \\
\hline & P16R11-3 & -3800 & 3320 \\
\hline & Average & -3513 & 3445 \\
\hline & Standard deviation & 301 & 380 \\
\hline & $\%$ increase $^{a}$ & 40.4 & 37.8 \\
\hline
\end{tabular}

${ }^{a}$ Improvement compare to the unreinforced control beam in average value.

\section{Theoretical model}

\subsection{Proposed methodology}

223 A general theoretical model for all reinforced or/and prestressed glulam beam in bending was used to predict the 224 resistant moment after the compressive strain of wood reaches elastic strain limits, as shown in Fig. 18. The 225 analytical values were then compared with experimental ones. This type of model has been used by most researchers dealing with reinforced glulam [10,11,24,35-40].

227 The model adopted here assumed the following:

228 - plane sections remain plane; 
- plane sections remain plane;

230

- bonding between CFRP bars and glulam was assumed as perfect;

- the stress-strain behaviour of timber was based on the model proposed by Bazan [39] and modified by Buchanan [40]: tension behavior was assumed to be linear-elastic for the glulam; a bilinear relationship was assumed for the compression behavior, with a linear part up to compressive strength $f_{\mathrm{wcu}}$ and a corresponding strain $\varepsilon_{\mathrm{wcy}}$; the slope of the descending branch was a constant fraction, $\mathrm{m}(\mathrm{m} \leqslant 0)$, of the modulus of elasticity of the timber, $E_{\mathrm{w}}(\mathrm{see}$ Fig. 19), $m=-0.25$ herein proposed by Lindyberg [41].

- the stress-strain relationship for the CFRP bar in tension and in compression was linear-elastic until failure (Fig. 20).

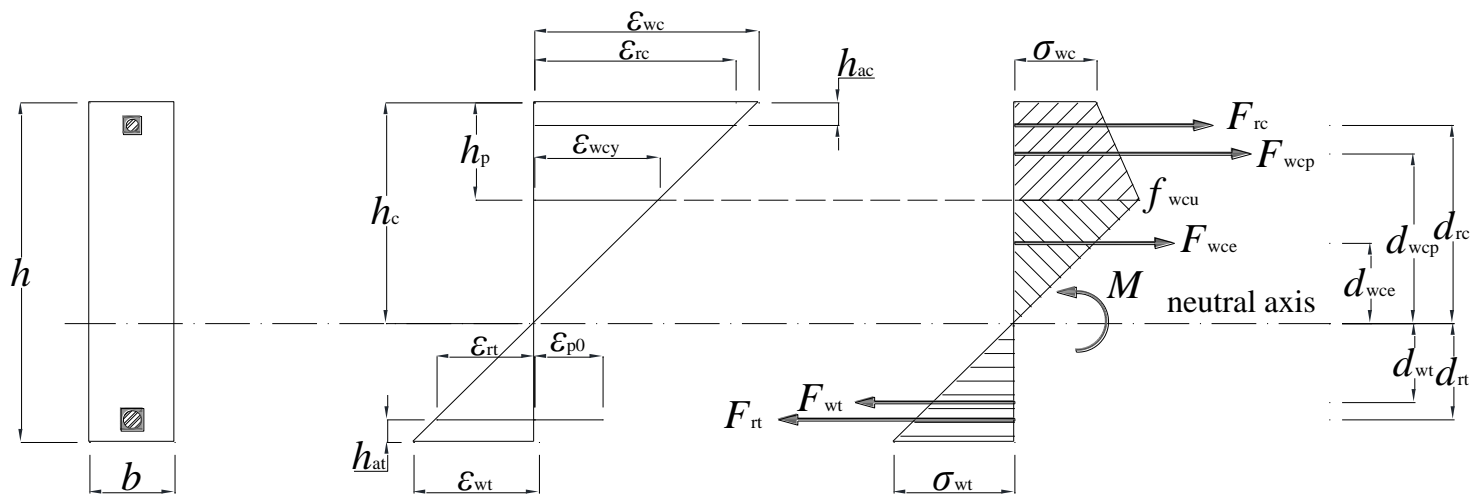

Fig. 18. Cross section of the glulam beam with the notation of the theoretical model.

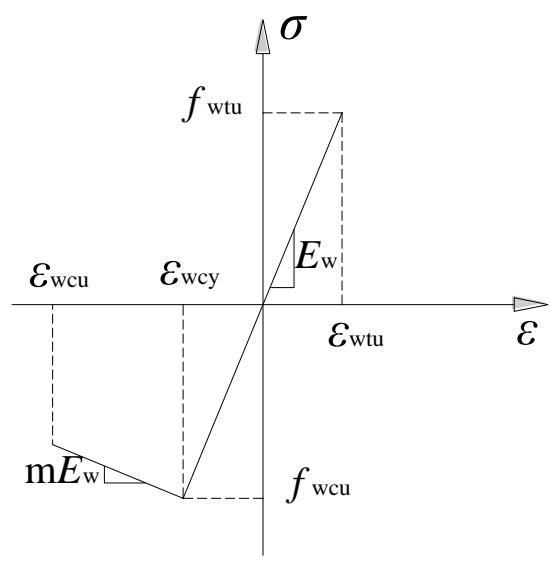

Fig. 19. Stress-strain relationship for glulam.

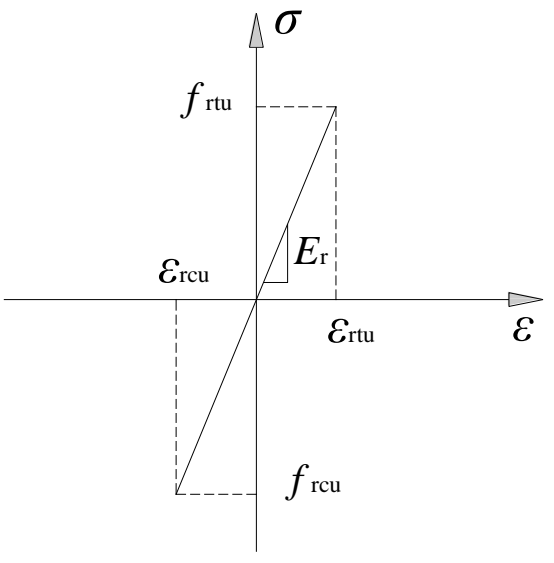

Fig. 20. Stress-strain relationship for CFRP bar.

As can be seen from Fig. 18, it is a general model for all kinds of beams. As to a passively reinforced glulam beams, the pre-existing strain $\left(\varepsilon_{\mathrm{p} 0}\right)$ in the prestressing CFRP bar is assumed to equal zero. While for the glulam beams reinforced only in the tension zone, the cross section of the CFRP bar $\left(A_{\mathrm{rc}}\right)$ and the internal force in the compression zone $\left(F_{\text {rc }}\right)$ are all assumed to equal zero then.

As a widely accepted fact, due to the stress distribution effect in a timber flexural members, the extreme fiber tensile 
stress at failure in bending, $f_{\mathrm{wm}}$, is greater than the axial tensile strength $f_{\mathrm{wtu}}$. And the relationship between these two parameters as indicated in Eq. (2), proposed by Madsen and Buchanan [42], was widely accepted worldwide and therefore adopted in this paper.

$$
f_{w m}=\left(\frac{k_{3}+1}{c}\right)^{1 / k_{3}} f_{w t u}
$$

Where $k_{3}$ (dimensionless): the stress distribution parameter; $c$ (dimensionless): the ratio of the depth of the neutral axis from the tension face with respect to the depth of the section.

In this investigation, however, it was not possible to obtain $f_{\text {wtu }}$ directly because of the limited samples of the axial strength test specimens. For this reason, the extreme fiber tensile stress at failure in bending, $f_{\mathrm{wm}}$, was obtained directly from the experimental mean strain values of the unreinforced glulam beams.

Since the presence of the reinforcement can remarkably improve the extreme fiber tensile strain of glulam at failure [11,33-36], a modification factor $\alpha_{\mathrm{m}}$ was introduced in the theoretical analysis to account for this enhancement of the tensile strength in bending, as proposed by Gentile et al. [11] and by Gentile [36]. Also it is considered that $\alpha_{\mathrm{m}}=1.3$, which was proposed by the authors [11,36], is reasonable when taking into account of these all experimental results including this research.

Thus the tensile strength in bending of reinforced glulam is:

$f_{w m r}=\alpha_{m} f_{w m}=\alpha_{m} E_{w} \varepsilon_{w m u}$

Where $f_{\mathrm{wmr}}(\mathrm{MPa})$ : the tensile strength in bending of reinforced timber; $\alpha_{\mathrm{m}}$ (dimensionless): a constant modification factor $\left(\alpha_{\mathrm{m}}=1.3\right.$, as proposed by the literature [11,36]); $E_{\mathrm{w}}(\mathrm{MPa})$ : Modulus of elasticity of timber; $\varepsilon_{\mathrm{wmu}}$ (dimensionless): the ultimate tensile strain of timber in bending.

Generally, since there was no yielding of the reinforcement, there are two typical flexural failure modes for reinforced or prestressed glulam beams:

- reinforced timber tensile failure as the extreme fiber tensile strain reaches ultimate tensile strain $\left(\varepsilon_{\mathrm{wt}}=\alpha_{\mathrm{m}} \varepsilon_{\mathrm{wmu}}\right)$;

- timber compressive failure as the extreme fiber compressive strain reaches ultimate compressive strain $\left(\varepsilon_{\mathrm{wc}}=1.2 \%\right.$, as assumed from Brunner [38]).

Then based on the theoretical model and the stress-strain relationships of the materials presented above, the neutral axis location and then the ultimate bending moment could be evaluated using the equilibrium condition on the cross section of the beam, as discussed in the following section.

\subsubsection{Flexural capacity for timber tensile failure}

According to the theoretical model shown in Fig. 18, the internal forces were defined by the following: 
278

$F_{w c e}=A_{w c e} \cdot f_{w c u} / 2=E_{w} b\left(h_{c}-h_{p}\right) \varepsilon_{w c y} / 2$

$F_{w t}=A_{w t} \cdot \sigma_{w t} / 2=E_{w} b\left(h-h_{c}\right) \varepsilon_{w t} / 2$

$F_{r t}=A_{r t} \sigma_{r t}+F_{p 0}=A_{r t} E_{r} \varepsilon_{r t}+F_{p 0}$

281 Where $h_{\mathrm{c}}(\mathrm{mm})$ : the depth of neutral axis; $h_{\mathrm{p}}(\mathrm{mm})$ : the depth of plastic compression zone; $F_{\mathrm{p} 0}(\mathrm{~N})$ : the prestress load 282 of the CFRP bar in tension zone $\left(F_{\mathrm{p} 0}=A_{\mathrm{r} t} E_{\mathrm{r}} \varepsilon_{\mathrm{p} 0}\right)$; the other parameters are all indicated in Fig. 18 to Fig. 20.

283 Since the failure is due to the timber tension failure, $\varepsilon_{\mathrm{wt}}$ was then given as $\alpha_{\mathrm{m}} \varepsilon_{\mathrm{wmu}}$. The other strain quantities can be calculated according to the assumption that the sections remain planar, as shown in Fig. 18:

$\varepsilon_{w c}=\frac{h_{c}}{h-h_{c}} \varepsilon_{w t}$

$\varepsilon_{w c y}=\frac{h-h_{p}}{h-h_{c}} \varepsilon_{w t} \Rightarrow h_{p}=\left(1+\frac{\varepsilon_{w c y}}{\varepsilon_{w t}}\right) h_{c}-\frac{\varepsilon_{w c y}}{\varepsilon_{w t}} h$

$\varepsilon_{r c}=\frac{h-h_{a c}}{h-h_{c}} \varepsilon_{w t}$

$\varepsilon_{r t}=\frac{h-h_{c}-h_{a t}}{h-h_{c}} \varepsilon_{w t}$

The internal force equilibrium requires that:

$F_{w t}+F_{r t}=F_{r c}+F_{w c e}+F_{w c p}$

Then the depth of neutral axis $h_{\mathrm{c}}$ can now be calculated:

292

$h_{c, f f}=\frac{-\mathrm{b}_{1} \pm \sqrt{\mathrm{b}_{1}^{2}-4 a_{1} c_{1}}}{2 a_{1}}$

where $h_{\mathrm{c}, \mathrm{ff}}(\mathrm{mm})$ : the depth of neutral axis corresponding to timber tensile failure;

$$
a_{1}=(m-1) E_{w} b\left(\alpha_{m} \varepsilon_{w m u}+\varepsilon_{w c y}\right)^{2} /\left(2 \alpha_{m} \varepsilon_{w m u}\right) ;
$$

$$
b_{1}=E_{r} \alpha_{m} \varepsilon_{w m u}\left(A_{r c}+A_{r t}\right)+F_{p 0}+\frac{E_{w} b h}{\alpha_{m} \varepsilon_{w m u}}\left[\alpha_{m}^{2} \varepsilon_{w m u}^{2}+(1-m) \varepsilon_{w c y}\left(\varepsilon_{w c y}+\alpha_{m} \varepsilon_{w m u}\right)\right]
$$

$$
c_{1}=\frac{E_{w} b h^{2}}{2 \alpha_{m} \varepsilon_{w m u}}\left[(m-1) \varepsilon_{w c y}^{2}-\alpha_{m}^{2} \varepsilon_{w m u}^{2}\right]-E_{r} \alpha_{m} \varepsilon_{w m u}\left(A_{r c} h_{a c}+A_{r t} h-A_{r t} h_{a t}\right)-F_{p 0} h .
$$


299 where $M_{\mathrm{tf}}(\mathrm{Nmm})$ : the resisting moment of glulam beams at timber tensile failure; the corresponding lever arms of the internal forces are:

$d_{r c}=\left(h_{c}-h_{a c}\right)$

$d_{w c p}=h_{c}-\frac{2\left(h-h_{c}\right) \varepsilon_{w c y}+h_{c} \alpha_{m} \varepsilon_{w m u}}{3\left[\left(h-h_{c}\right) \varepsilon_{w c y}+h_{c} \alpha_{m} \varepsilon_{w m u}\right]} h_{p}$

$d_{w c e}=2\left(h_{c}-h_{p}\right) / 3$

$d_{w t}=2\left(h-h_{c}\right) / 3$

$d_{r t}=h-h_{c}-h_{a t}$

\subsubsection{Flexural capacity for timber compressive failure}

In this phase, only the timber in compression has exceeded its plastic limit and the given condition is $\varepsilon_{\mathrm{wc}}=1.2 \%$, as assumed from Brunner [38]. Then the depth of neutral axis $h_{\mathrm{c}}$ can now be found out as following:

$h_{c, c f}=\frac{-\mathrm{b}_{2} \pm \sqrt{\mathrm{b}_{2}^{2}-4 a_{2} c_{2}}}{2 a_{2}}$

where $h_{\mathrm{c}, \mathrm{cf}}(\mathrm{mm})$ : the depth of neutral axis corresponding to timber compressive failure;

$$
a_{2}=(m-1) E_{w} b\left(\varepsilon_{w c u}-\varepsilon_{w c y}\right)^{2} /\left(2 \varepsilon_{w c u}\right) ;
$$

$$
b_{2}=E_{r} \varepsilon_{w c u}\left(A_{r c}+A_{r t}\right)-F_{p 0}+E_{w} b h \varepsilon_{w c u} ;
$$

$$
c_{2}=\varepsilon_{w c u}\left[E_{r} A_{r t}\left(h_{a t}-h\right)-E_{r} A_{r c} h_{a c}-E_{w} b h^{2} / 2\right] .
$$

314 The resultant resisting moment is then found out to be:

$$
M_{c f}=F_{r c} d_{r c}+F_{w c p} d_{w c p}+F_{w c e} d_{w c e}+F_{w t} d_{w t}+F_{r t} d_{r t}
$$

where $M_{\mathrm{cf}}(\mathrm{Nmm})$ : the resisting moment of glulam beams at timber compressive failure.

And the corresponding lever arms are the same as above except that:

$d_{w c p}=h_{c}-\frac{2 \varepsilon_{w c y}+\varepsilon_{w c u}}{3\left(\varepsilon_{w c y}+\varepsilon_{w c u}\right)} h_{p}$

Then it can be determined by comparing the calculating results from Eq. (15) and Eq. (22), the ultimate bending moment could be:

$$
M_{u}=\min \left\{M_{t f}, M_{c f}\right\}
$$




\subsubsection{Bending stiffness}

323

The bending stiffness of glulam beams reinforced or prestressed with CFRP bars was computed based on the transformed section method using Eq. (25).

$$
E I=E_{w}\left[I_{w}+\left(\alpha_{E}-1\right) A_{r t}\left(h / 2-h_{a t}\right)^{2}+\left(\alpha_{E}-1\right) A_{r c}\left(h / 2-h_{a c}\right)^{2}\right]
$$

where $I_{\mathrm{w}}\left(\mathrm{mm}^{4}\right)$ : the section moment of inertia of unreinforced glulam beam; $\alpha_{\mathrm{E}}$ (dimensionless): the modulus of elasticity ratio of CFRP bar to glulam beam.

\subsection{Comparison of theoretical analysis to test data}

\section{Table 6}

Comparison between theoretical and experimental results.

\begin{tabular}{llllllll}
\hline \multirow{2}{*}{$\begin{array}{l}\text { Series } \\
\text { reference }\end{array}$} & \multicolumn{2}{l}{ Bending stiffness $E I\left(10^{12} \mathrm{Nmm}^{2}\right)$} & & \multicolumn{3}{l}{ Flexural capacity $M_{\mathrm{u}}(\mathrm{kNm})$} \\
\cline { 2 - 3 } & $\begin{array}{l}\text { Experimental } \\
\text { results }\end{array}$ & $\begin{array}{l}\text { Analytical } \\
\text { results }\end{array}$ & $\begin{array}{l}\text { Difference } \\
(\%)\end{array}$ & & $\begin{array}{l}\text { Experimental } \\
\text { results }\end{array}$ & $\begin{array}{l}\text { Analytical } \\
\text { results }\end{array}$ & $\begin{array}{l}\text { Difference } \\
(\%)\end{array}$ \\
\hline $\mathrm{C}$ & 1.96 & 2.11 & +7.7 & & 35.3 & 30.9 & -12.4 \\
$\mathrm{R} 11$ & 2.33 & 2.35 & +0.8 & & 58.3 & 50.5 & -13.4 \\
$\mathrm{P} 16$ & 2.61 & 2.63 & +0.8 & & 68.3 & 66.1 & -3.2 \\
$\mathrm{P} 16 \mathrm{R} 11^{\mathrm{a}}$ & 2.79 & 2.87 & +2.9 & & 81.5 & 72.1 & -11.6 \\
\hline
\end{tabular}

${ }^{\mathrm{a}}$ It showed experimental flexure-shear failure modes for this series.

Using the assumptions and procedure that were previously described, the flexural capacity and bending stiffness were calculated and compared with the corresponding experimental results (Table 6). The predicted flexural capacity $M_{\mathrm{u}}$ and bending stiffness EI were calculated using Eq. (15,22,24) and Eq. (25), respectively.

As can be seen from Table 6, the analytical values agreed well with the experimental mean values. The predicted bending stiffness showed an even greater accuracy. While the predicted flexural capacity was lower (from $3.2 \%$ to $13.4 \%$ ) than that of experimental results, indicating that the theoretical model was much more conservative for the flexural capacity prediction.

Through the theoretical model of this research, it can also predict the influence of both the prestressing and the increase area of reinforcement. For example, given a passive reinforcement with one 16 mm diameter CFRP bars (reinforcement ratio is $0.89 \%$ ), the flexural capacity will then be calculated to be $58.5 \mathrm{kN}$, which indicates an improvement of $15.8 \%$ when compared to series R11 (with passive reinforcement ratio of $0.42 \%$ ). Since the overall improvement of the flexural capacity is $30.9 \%$ by comparing series P16 with R11 based on the theoretical analysis (see Table 6), an increase of the flexural capacity can be then obtained to be $15.1 \%$ due to the prestressing. Thus it can be seen that both the prestressing and the increase area of reinforcement has notable influence on the flexural capacity.

Furthermore, the correlation of the calculated and experimental values of the flexural capacity is presented in Fig. 21, 
which includes the test data from the literature [36,37,41]. It should be noted that the specimens of "Beam 1" and "Beam 2" of the literature [37] were prestressed timber members, while "C series" of this work, HS0 of the literature [36], $0 \% \mathrm{WH}$ and $0 \% \mathrm{DF}$ of the literature [41] were unreinforced timber beams. All of the others were passively reinforced timber beams. It shows a good agreement between the analytical results and the experimental ones from different research and different reinforcing types, with the $\mathrm{R}^{2}$ value was 0.89 . However it still need further verification due to the limited sample size.

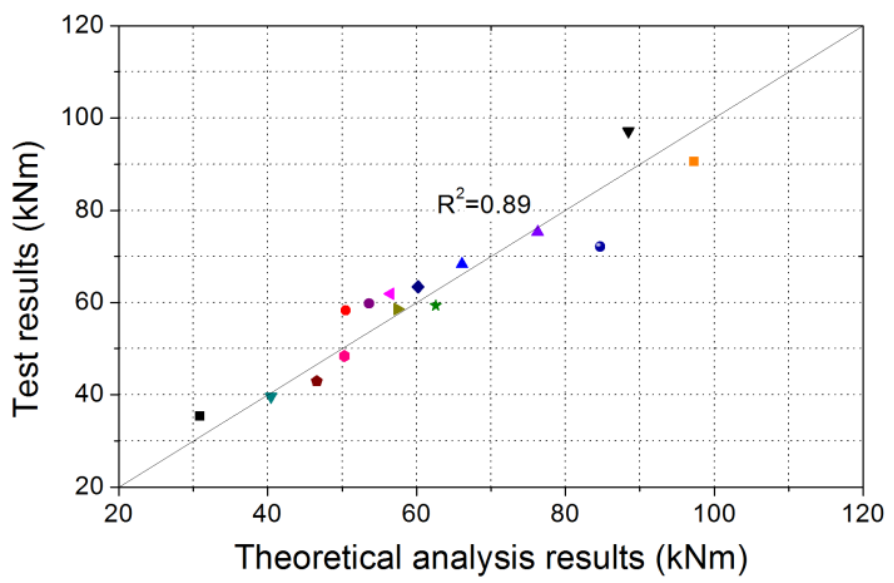

- This work ( $\mathrm{C}$ series)

- This work (R11 series)

- This work (P16 series)

v Gentile [36] (HSO)

4 Gentile [36] (HS27)

- Gentile [36] (HS41)

- Gentile [36] (HS82)

- Persson et al. [37] (Beam 1)

- Persson et al. [37] (Beam 2)

* Lindyberg [41] (0\% WH)

- Lindyberg [41] (1.1\% WH)

- Lindyberg [41] (3.3\% WH)

- Lindyberg [41] (0\% DF)

- Lindyberg [41] (1.1\% DF)

v Lindyberg [41] (3.3\% DF)

Fig. 21. Correlation of the calculated and experimental values of flexural capacity

\section{Conclusions}

The following conclusions may be drawn from the research regarding the reinforcement and prestressing of the Douglas fir glulam beams with CFRP bars.

- Unreinforced control glulam beams failed with a brittle failure due to the flexural tension failure of timber in tension zone.

- Both passively reinforced and prestressed glulam beams show a ductile behaviour with timber compressive failure.

- For prestressed \& reinforced glulam beams, it failed in a flexural-shear failure mode, which can be prevented by either decreasing the reinforcement ratio of the CFRP bar or increasing the cross section of glulam beam.

- Passively reinforced glulam beams using CFRP bar with a $0.42 \%$ reinforcement ratio can significantly improve the flexural capacity from $35.3 \mathrm{kNm}$ to $58.3 \mathrm{kNm}$, which represent an increase of $64.8 \%$. While the bending stiffness increases about $18.7 \%$.

- Prestressed glulam beams using CFRP bar with a $0.89 \%$ reinforcement ratio results in an enhancement of the ultimate capacity by $93.3 \%$ and a notable increase of bending stiffness by $33.2 \%$.

- Glulam beams both prestressed in tension zone and reinforced in compression zone increases the flexural capacity and bending stiffness by $131 \%$ and $42 \%$, respectively. 
- As a result from the prestress and pre-camber in the prestressed glulam beams, the load-carrying capacity at the beam deflection of $1 / 250$ of the beam span can be greatly improved. This improvement increases from $13.2 \mathrm{kN}$ to $41.0 \mathrm{kN}$, which indicates an increase of $211 \%$.

- Based on the theoretical model, both the prestressing and the increase area of reinforcement has a notable influence on the flexural capacity.

- Combined longitudinally bonding with end anchorages of the CFRP bars resulted into a good compatibility of deformation and therefore showed an obvious integrity.

- The flexural capacity of the unreinforced glulam beams was well predicted using a theoretical model based on work by Buchanan [40]. The model was modified to account for the presence of CFRP bars.

- The addition of the reinforcement, either passively reinforced or prestressed, could increase the tensile strain or strength of the timber beams in tension zone (increased by $24.3 \%$ to $77.6 \%$ from the experimental values). A constant modification factor $\alpha_{\mathrm{m}}=1.3$, as proposed by Gentile et al. [11,36], was considered reasonable.

- Correlation of the calculated and experimental values of several different research works showed satisfactory agreement, therefore the theoretical method presented a practical approach to discriminate the flexural behaviour of the FRP reinforced timber beams with different reinforcement ratios and reinforcing types.

\section{Acknowledgments}

This research work was supported by the National Science Foundation of China (Grant No. 51378256) and the National High Technology Research and Development Program of China (863 Program) (Grant No. 2012AA03A204), which are highly appreciated.

\section{References}

[1] Anshari B, Guan Z, Komatsu K, Kitamori A, Jung K. Explore novel ways to strengthen glulam beams by using compressed Japanese cedar. In: Proceedings of the world conference on timber engineering (WCTE), 20-24 June 2010, Trentino (Italy): Riva del Garda; 2010. p. 8.

[2] McConnell E, McPolin D, Taylor S. Post-tensioning of glulam timber with steel tendons. Constr Build Mater 2014; 73: 426-33.

[3] Kliger R, Johansson M, Crocetti R. Strengthening timber with CFRP or steel plates - short and long-term performance. In: Proceedings of 9th world conference on timber engineering, WCTE 2008, Miyazaki, Japan; vol. II, 2008. p. 517-22.

[4] Mark R. Wood-aluminum beams within and beyond the elastic range. Part 1: rectangular sections. For Prod J 
$1961 ; 11(10): 477-84$.

401 [5] Bohannan B. Prestressed wood members. For Prod J 1962; 12(12): 596-602.

402 [6] Lantos G. The flexural behavior of steel reinforced laminated timber beams. Wood Sci 1970: 2(3): 136-43.

403 [7] Bulleit WM, Sandberg LB, Woods GJ. Steel-reinforced glued laminated timber. J Struct Eng, ASCE 1989; 404 115(2): 433-44.

[8] Spaun FD. Reinforcement of wood with fiberglass. For Prod J 1981; 31(4): 26-33.

[9] Van de Kuilen JWG. Theoretical and experimental research on glass fibre reinforced laminated timber beams. In: Proceedings of the international timber engineering conference, London, England; Vol. 3, 1991. p. 226-33.

[10] Plevris N, Triantafillou TC. FRP-reinforced wood as structural material. J Mater Civ Eng, ASCE 1992; 4(3): $300-17$.

[11] Gentile C, Svecova D, Rizkalla SH. Timber beams strengthened with GFRP bars: development and applications. J Compos Const 2002; 6(1): 11-20.

[12] Fiorelli J, Alves DA. Analysis of the strength and stiffness of timber beams reinforced with carbon fiber and glass fiber. Mater Res 2003; 6(2): 193-202.

[13] Yang H, Liu W. Study on flexural behavior of FRP reinforced glulam beams. Jianzhu Jiegou Xuebao / J Build Struct 2007; 28(1): 64-71 [in Chinese].

[14] Kim YJ, Harries KA. Modeling of timber beams strengthened with various CFRP composites. Eng Struct 2010; 32: $3225-34$.

[15] Khelifa M, Celzard A. Numerical analysis of flexural strengthening of timber beams reinforced with CFRP strips. Compos Struct 2014; 111: 393-400.

[16] Raftery GM, Whelan C. Low-grade glued laminated timber beams reinforced using improved arrangements of bonded-in GFRP rods. Constr Build Mater 2014; 52: 209-20.

[17] Raftery GM, Harte AM. Low-grade glued laminated timber reinforced with FRP plate. Compos Part B: Eng 2011; (42)4: 724-35.

[18] Raftery GM, Harte AM. Nonlinear numerical modeling of FRP plate reinforced glued laminated timber. Compos Part B: Eng 2013; 52: 40-50.

[19] Raftery GM, Rodd PD. FRP reinforcement of low-grade glulam timber bonded with wood adhesive. Constr Build Mater 2015; 91: 116-25.

[20] Hansson S, Karlsson K. Moisture related creep of reinforced timber - theoretical studies and laboratory tests. Master's thesis. Department of Civil and Environmental Engineering, Chalmers University of Technology; 
2007.

[21] Martin ZA, Stith JK, Tingley DA. Commercialisation of FRP reinforced glulam beam technology. In: Proceedings of the 6th world conference on timber engineering, Whistler Resort, Canada, UBC Press; 2000.

[22] Negrao J, Brunner M, Lehmann M. Pre-stressing of timber. Bonding of timber: core document of the COST Action E34. Vienna: University of Natural Resources and Applied Life Sciences; 2008.

[23] Guan ZW, Rodd PD, Pope DJ. Study of glulam beams pre-stressed with pultruded GRP. Comput Struct 2005; 83(28): $2476-87$

[24] Brady JF, Harte AM. Prestressed FRP flexural strengthening of softwood glue-laminated timber beams. In: Proceedings of 9th world conference on timber engineering, WCTE 2008, Miyazaki, Japan; 2008.

[25] De Luca V, Marano C. Prestressed glulam timbers reinforced with steel bars. Constr Build Mater 2012; 30: $206-17$.

[26] Al-Hayek H, Svecova D. Flexural Strength of Posttensioned Timber Beams. J Compos Constr 2014; 18(2), 04013036. http://dx.doi.org/10.1061/(ASCE)CC.1943-5614.0000431.

[27] Negrão JH. Preliminary study on wire prestressing methods for timber pieces reinforcement. Constr Build Mater 2016; 102: 1093-100.

[28] British Standards Institution. BS EN 13183-1:2002. Moisture content of a piece of a sawn timber - Part 1: determination by oven dry method: BSI; 2002.

[29] British Standards Institution. BS EN 408:2010 Timber structures. Structural timber and glued laminated timber. Determination of some physical and mechanical properties: BSI; 2010.

[30] British Standards Institution. BS EN 1194:1999 Timber structures. Glued laminated timber. Strength classes and determination of characteristic values: BSI; 1999.

[31] Morano S, Mannini C. Preflex Beams: A method of calculation of creep and shrinkage effects. J Bridge Eng 2006; 11(1): 48-58.

[32] Schmidt JW, Bennitz A, Täljsten B, Goltermann P, Pedersen H. Mechanical anchorage of FRP tendons - A literature review. Constr Build Mater 2012; 32: 110-21.

[33] Yang H. Study on flexural behavior of wood composite beams made from fast-growing timber. PhD thesis. College of Civil Engineering, Nanjing Tech University; 2007. [in Chinese].

[34] Johns KC, Lacroix S. Composite reinforcement of timber in bending. Can J Civil Eng 2000; 27(5): 899-906.

[35] Garzon Barragán O, Jacob J. Flexural strengthening of glued laminated timber beams with steel and carbon fiber reinforced polymers. Master's thesis. Department of Civil and Environmental Engineering, Chalmers 
University of Technology; 2007.

461 [36] Gentile CJ. Flexural strengthening of timber bridge beams using FRP. Master's thesis. Department of Civil \& Geological Engineering, University of Manitoba; 2000.

463 [37] Persson MP, Wogelberg S. Analytical models of pre-stressed and reinforced glulam beams, a competitive analysis of strengthened glulam beams. Master's thesis. Department of Civil and Environmental Engineering, Chalmers University of Technology; 2011.

466 [38] Brunner M. On the plastic design of timber beams with a complex cross-section. In: World conference on timber engineering, British Columbia, Canada, July 31-August 3, 2000; 2000.

[39] Bazan IMM. Ultimate bending strength of timber beams. PhD thesis, Nova Scotia Technical College, Halifax, Nova Scotia, Canada; 1980.

470 [40] Buchanan AH. Bending strength of lumber. J Struct Eng 1990; 116(5): 1213-29.

471 [41] Lindyberg RF. ReLAM: A nonlinear probabilistic model for the analysis of reinforced glulam beams in bending. $\mathrm{PhD}$ thesis, University of Maine; 2000.

[42] Madsen B, Buchanan AH. Size effects in timber explained by a modified weakest link theory. Can J Civil Eng 1986; 13(2): 218-32. 
Table 1

Characteristic strength and stiffness properties of homogeneous glulam.

\begin{tabular}{llll}
\hline Material property & Test results (N/mm $)$ & GL 28h [30] (N/mm²) & GL 36h [30] $\left(\mathrm{N} / \mathrm{mm}^{2}\right)$ \\
\hline Tension strength parallel to grain & 32.8 & 19.5 & 26.0 \\
Compression strength parallel to grain & 37.0 & 26.5 & 31.0 \\
Modulus of elasticity parallel to grain, mean value & 12,500 & 12600 & 14700 \\
Modulus of elasticity parallel to grain, 5\% value & 11,400 & 10200 & 11900 \\
\hline
\end{tabular}

Table 2

Mechanical properties of the epoxy resin provided by the manufacturer.

\begin{tabular}{ll}
\hline Specification & Value $\left(\mathrm{N} / \mathrm{mm}^{2}\right)$ \\
\hline Compressive strength & 70.0 \\
Bending strength & 65.0 \\
Splitting strength & 9.2 \\
Modulus of elastic in tension & 3320 \\
\hline
\end{tabular}

Table 3

Series and specimen information.

\begin{tabular}{|c|c|c|c|c|c|c|c|}
\hline \multirow{2}{*}{$\begin{array}{l}\text { Series } \\
\text { reference }\end{array}$} & \multirow{2}{*}{$\begin{array}{l}\text { No. of } \\
\text { replicates }\end{array}$} & \multicolumn{6}{|l|}{ Reinforcement } \\
\hline & & Type & Location & $\begin{array}{l}\text { Diameter } \\
(\mathrm{mm})\end{array}$ & Anchorage type & $\begin{array}{l}\text { Cross-section } \\
\text { ratio }(\%)\end{array}$ & $\begin{array}{c}\text { Prestress force }{ }^{c} \\
(\mathrm{kN})\end{array}$ \\
\hline $\mathrm{C}$ & 3 & - & - & - & - & 0.00 & - \\
\hline R11 & 3 & $\begin{array}{l}\text { passive } \\
\text { reinforcement }\end{array}$ & Bottom & 11 & $\begin{array}{c}\text { End anchor and } \\
\text { bonded }\end{array}$ & 0.42 & 0.0 \\
\hline P16 & 3 & prestressed & Bottom & 16 & $\begin{array}{c}\text { End anchor and } \\
\text { bonded }\end{array}$ & 0.89 & 50.8 \\
\hline P16R11 & 3 & $\begin{array}{c}\text { prestressed and } \\
\text { reinforcement }\end{array}$ & Bottom and top & $\begin{array}{c}16 \text { and } \\
11^{\mathrm{a}}\end{array}$ & $\begin{array}{c}\text { End anchor and } \\
\text { bonded }\end{array}$ & 0.89 and $0.42^{\mathrm{b}}$ & 50.8 \\
\hline
\end{tabular}

${ }^{\mathrm{a}}$ Bottom prestressed bar was $16 \mathrm{~mm}$ in diameter and top reinforced bar was $11 \mathrm{~mm}$ in diameter.

${ }^{\mathrm{b}}$ Cross-section ratio for bottom prestressed bar was 0.89 and for top reinforced bar was 0.42 .

${ }^{\mathrm{c}}$ Prestress force was average strain values of the CFRP bars at mid-point of the three glulam beams in each series. 
Table 4

Comparison of experimentally obtained results.

\begin{tabular}{|c|c|c|c|c|c|c|}
\hline Specimen type & Beam code & $\begin{array}{l}\text { Failure } \\
\text { load } \\
F_{\mathrm{u}}(\mathrm{kN})\end{array}$ & $\begin{array}{l}\text { Failure } \\
\text { moment } M_{\mathrm{u}} \\
(\mathrm{kNm})\end{array}$ & $\begin{array}{l}\text { Load at the mid-span } \\
\text { deflection reached } \\
L / 250 F_{\mathrm{L} / 250}(\mathrm{kN})\end{array}$ & $\begin{array}{l}\text { Stiffness } \\
E_{\mathrm{mg}} I \\
\left(10^{12} \mathrm{Nmm}^{2}\right)\end{array}$ & Failure modes \\
\hline \multirow{5}{*}{$\begin{array}{l}\text { Unreinforced } \\
\text { control beam } \\
\text { (C series) }\end{array}$} & $\mathrm{C}-1$ & 33.5 & 31.8 & 13.7 & 2.03 & Tension \\
\hline & $\mathrm{C}-2$ & 39.0 & 37.1 & 12.7 & 1.91 & Tension \\
\hline & $\mathrm{C}-3$ & 39.3 & 37.1 & 13.1 & 1.94 & Tension \\
\hline & Average & 37.3 & 35.3 & 13.2 & 1.96 & - \\
\hline & $\begin{array}{l}\text { Standard } \\
\text { deviation }\end{array}$ & 3.3 & 3.0 & 0.50 & 0.06 & - \\
\hline \multirow{6}{*}{$\begin{array}{l}\text { Reinforced beam } \\
\text { (R11 series) }\end{array}$} & $\mathrm{R} 11-1$ & 59.1 & 56.1 & 17.0 & 2.52 & Compression \\
\hline & R11-2 & 57.3 & 54.4 & 16.1 & 2.13 & Compression \\
\hline & $\mathrm{R} 11-3$ & 67.7 & 64.3 & 16.7 & 2.33 & Compression \\
\hline & Average & 61.3 & 58.3 & 16.6 & 2.33 & - \\
\hline & $\begin{array}{l}\text { Standard } \\
\text { deviation }\end{array}$ & 5.6 & 5.3 & 0.46 & 0.18 & - \\
\hline & $\%$ increase $^{a}$ & 64.8 & 64.8 & 26.1 & 18.9 & - \\
\hline \multirow{6}{*}{$\begin{array}{l}\text { Prestressed beam } \\
\text { (P16 series) }\end{array}$} & P16-1 & 65.6 & 62.3 & 39.7 & 2.62 & Compression \\
\hline & $\mathrm{P} 16-2$ & 70.9 & 67.4 & 38.0 & 2.61 & Compression \\
\hline & $\mathrm{P} 16-3^{\mathrm{b}}$ & 79.2 & 75.2 & - & - & Compression \\
\hline & Average & 71.9 & 68.3 & 38.9 & 2.61 & - \\
\hline & $\begin{array}{l}\text { Standard } \\
\text { deviation }\end{array}$ & 6.9 & 6.5 & 1.20 & 0.01 & - \\
\hline & $\%$ increase $^{a}$ & 93.3 & 93.3 & 195.1 & 33.2 & - \\
\hline \multirow{6}{*}{$\begin{array}{l}\text { Prestressed \& } \\
\text { reinforced beam } \\
\text { (P16R11 series) }\end{array}$} & P16R11-1 & 90.6 & 86.1 & 41.8 & 2.91 & Flexure-shear \\
\hline & P16R11-2 & 82.7 & 78.6 & 41.2 & 2.84 & Flexure-shear \\
\hline & P16R11-3 & 84.2 & 80.0 & 40.0 & 2.61 & Flexure-shear \\
\hline & Average & 85.9 & 81.5 & 41.0 & 2.79 & - \\
\hline & $\begin{array}{l}\text { Standard } \\
\text { deviation }\end{array}$ & 4.2 & 4.0 & 0.92 & 0.14 & - \\
\hline & $\%$ increase $^{a}$ & 131 & 131 & 211.4 & 42.3 & - \\
\hline
\end{tabular}

${ }^{\mathrm{a}}$ Improvement compare to the unreinforced control beam in average value.

${ }^{\mathrm{b}}$ The deflection and stiffness values are not available due to the faulty LVDT. 


\section{Table 5}

Comparison of extreme fiber strain at failure of the specimens.

\begin{tabular}{|c|c|c|c|}
\hline Specimen type & Beam code & $\begin{array}{l}\text { Extreme fiber compressive strain } \\
\varepsilon_{\mathrm{c}, \max }(\text { microstrain })\end{array}$ & $\begin{array}{l}\text { Extreme fiber tensile strain } \\
\varepsilon_{\mathrm{t}, \max }(\text { microstrain })\end{array}$ \\
\hline \multirow{5}{*}{$\begin{array}{l}\text { Unreinforced control beam } \\
\text { (C series) }\end{array}$} & $\mathrm{C}-1$ & -2758 & 2288 \\
\hline & $\mathrm{C}-2$ & -1724 & 2572 \\
\hline & $\mathrm{C}-3$ & -3025 & 2638 \\
\hline & Average & -2502 & 2499 \\
\hline & Standard deviation & 687 & 186 \\
\hline \multirow{6}{*}{$\begin{array}{l}\text { Reinforced beam } \\
\text { (R11 series) }\end{array}$} & $\mathrm{R} 11-1$ & -4110 & 4450 \\
\hline & $\mathrm{R} 11-2$ & -4120 & 4550 \\
\hline & R11-3 & -5500 & 4317 \\
\hline & Average & -4577 & 4439 \\
\hline & Standard deviation & 800 & 117 \\
\hline & $\%$ increase $^{a}$ & 82.9 & 77.6 \\
\hline \multirow{6}{*}{$\begin{array}{l}\text { Prestressed beam } \\
\text { (P16 series) }\end{array}$} & P16-1 & -5625 & 3300 \\
\hline & $\mathrm{P} 16-2$ & -3810 & 2820 \\
\hline & P16-3 & -4690 & 3200 \\
\hline & Average & -4708 & 3107 \\
\hline & Standard deviation & 908 & 253 \\
\hline & $\%$ increase $^{a}$ & 88.2 & 24.3 \\
\hline \multirow{6}{*}{$\begin{array}{l}\text { Prestressed \& reinforced beam } \\
\text { (P16R11 series) }\end{array}$} & P16R11-1 & -3541 & 3871 \\
\hline & P16R11-2 & -3199 & 3143 \\
\hline & P16R11-3 & -3800 & 3320 \\
\hline & Average & -3513 & 3445 \\
\hline & Standard deviation & 301 & 380 \\
\hline & $\%$ increase $^{a}$ & 40.4 & 37.8 \\
\hline
\end{tabular}

${ }^{\mathrm{a}}$ Improvement compare to the unreinforced control beam in average value.

\section{Table 6}

Comparison between theoretical and experimental results.

\begin{tabular}{llllllll}
\hline \multirow{2}{*}{$\begin{array}{l}\text { Series } \\
\text { reference }\end{array}$} & \multicolumn{2}{l}{ Bending stiffness $E I\left(10^{12} \mathrm{Nmm}^{2}\right)$} & & \multicolumn{3}{l}{ Flexural capacity $M_{\mathrm{u}}(\mathrm{kNm})$} \\
\cline { 2 - 4 } & $\begin{array}{l}\text { Experimental } \\
\text { results }\end{array}$ & $\begin{array}{l}\text { Analytical } \\
\text { results }\end{array}$ & $\begin{array}{l}\text { Difference } \\
(\%)\end{array}$ & & $\begin{array}{l}\text { Experimental } \\
\text { results }\end{array}$ & $\begin{array}{l}\text { Analytical } \\
\text { results }\end{array}$ & $\begin{array}{l}\text { Difference } \\
(\%)\end{array}$ \\
\hline $\mathrm{C}$ & 1.96 & 2.11 & +7.7 & & 35.3 & 30.9 & -12.4 \\
$\mathrm{R} 11$ & 2.33 & 2.35 & +0.8 & & 58.3 & 50.5 & -13.4 \\
$\mathrm{P} 16$ & 2.61 & 2.63 & +0.8 & & 68.3 & 66.1 & -3.2 \\
$\mathrm{P} 16 \mathrm{R} 11^{\mathrm{a}}$ & 2.79 & 2.87 & +2.9 & & 81.5 & 72.1 & -11.6 \\
\hline
\end{tabular}

${ }^{\mathrm{a}}$ It showed experimental flexure-shear failure modes for this series. 


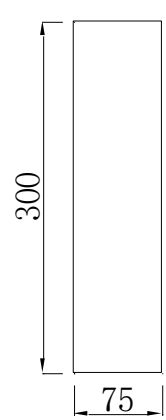

C series

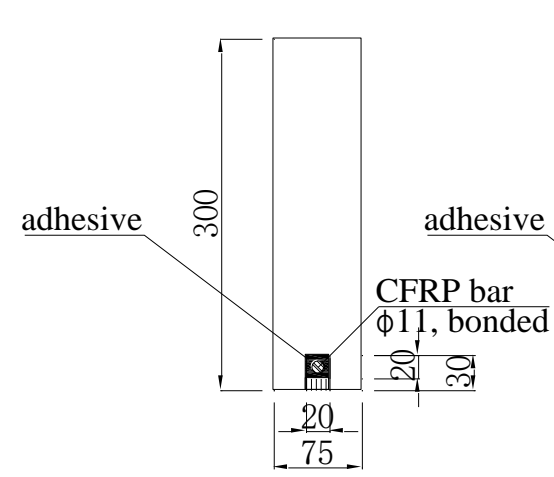

R11 series

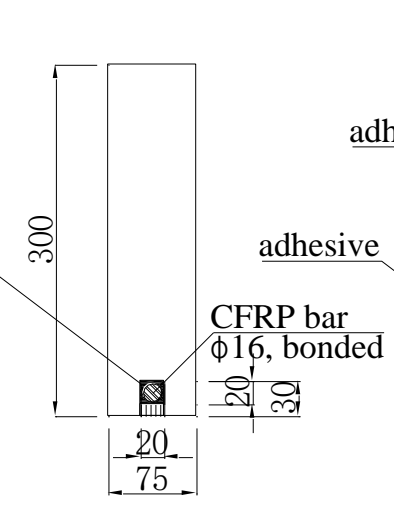

P16 series

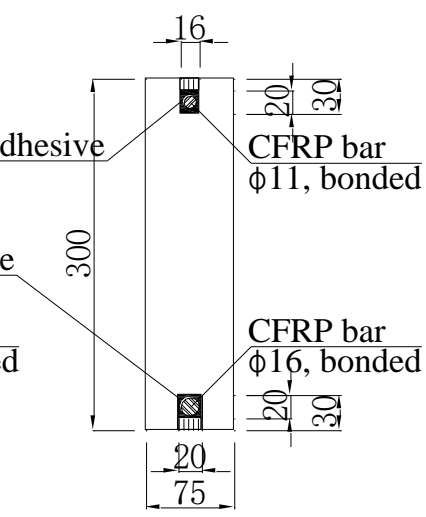

P16R11 series

unreinforced control bottom reinforced

bottom prestressed

bottom prestressed \& top reinforced

Fig. 1. Details of cross section types.

(a)

(b)

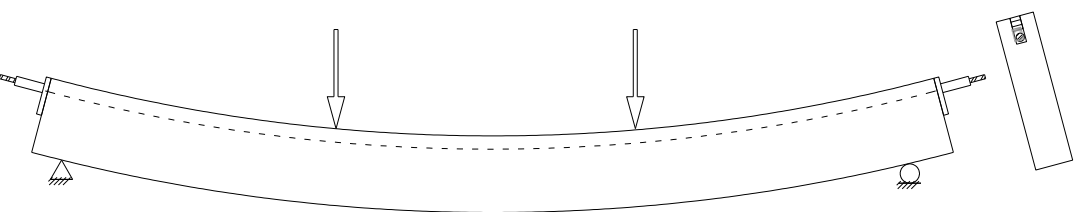

(c)

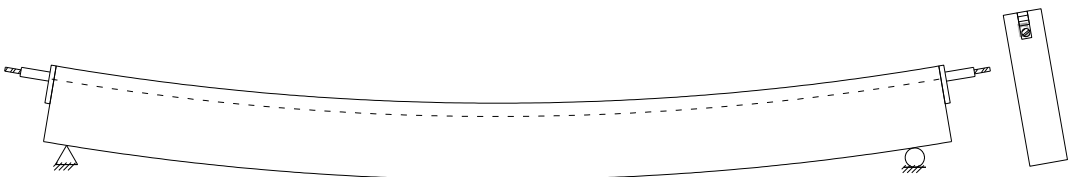

(d)

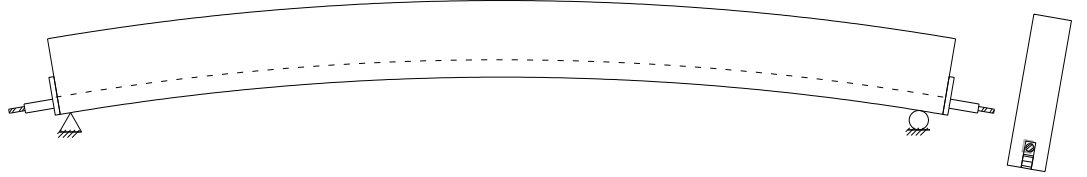

Fig. 2. Phases of construction of prestressed beam: (a) assemblage of glulam beam, (b) pre-deflection of glulam beam and filling the slots with adhesive, (c) release of glulam beam after the adhesive is well cured and (d) Overturn of glulam beam and prepare to test. 


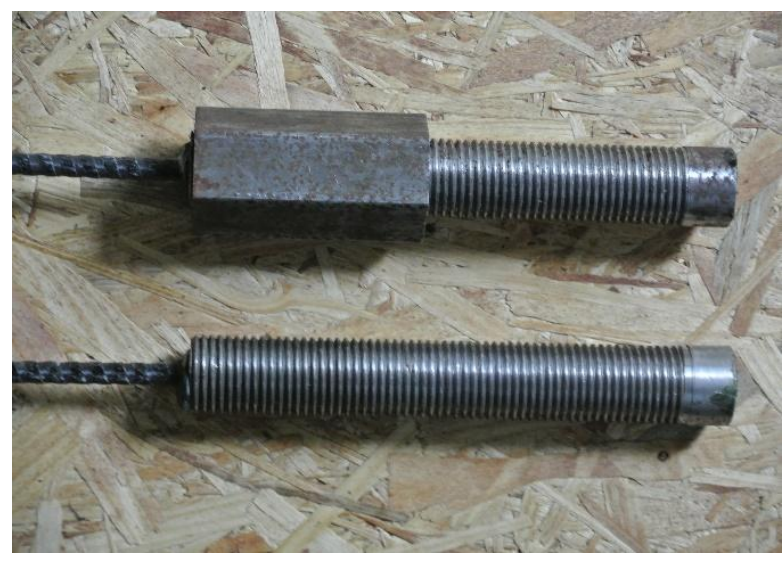

Fig. 3. Straight sleeve anchorages with nuts.

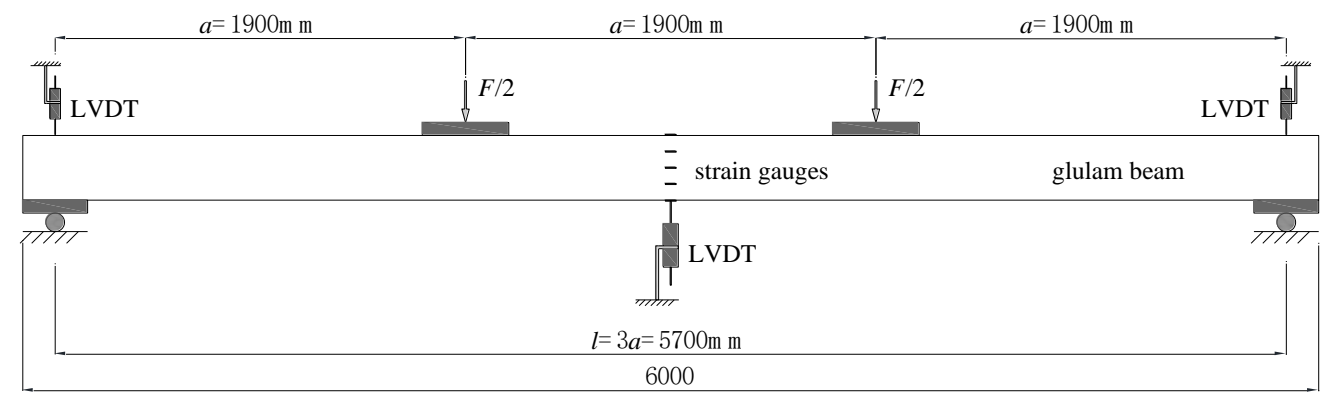

Fig. 4. Test set-up and arrangement.

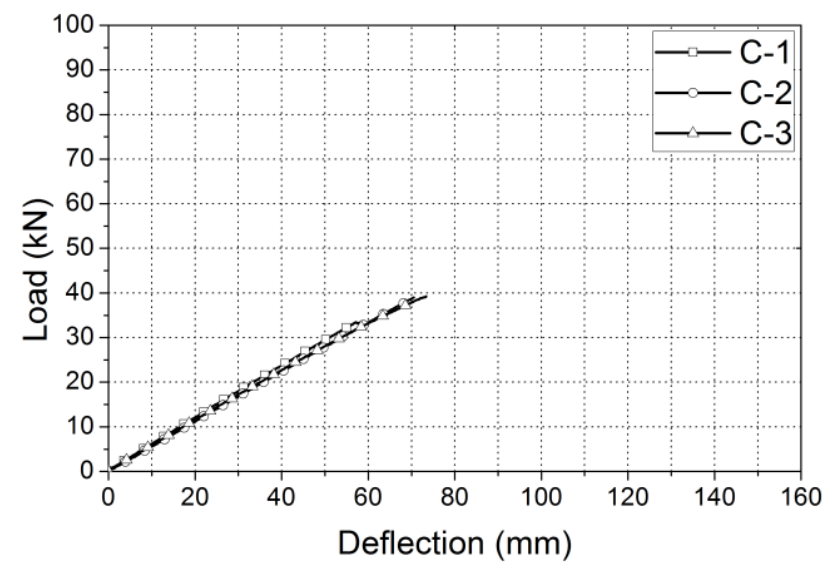

Fig. 5. Load-deflection curve for the unreinforced control beams (C series). 


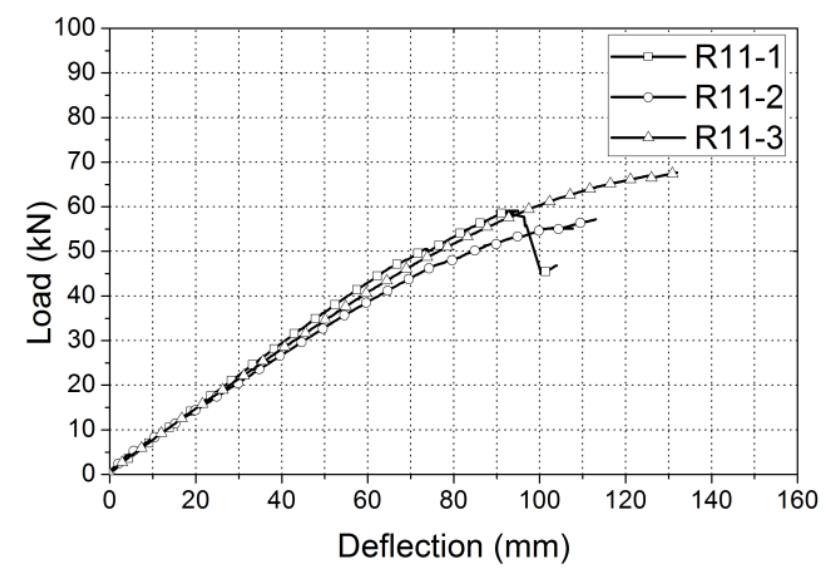

Fig. 6. Load-deflection curve for the bottom reinforced beams (R11 series).

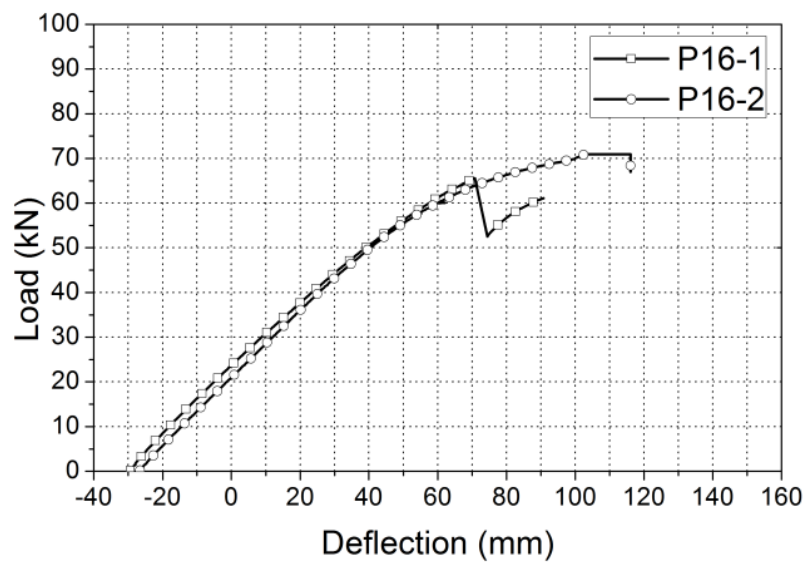

Fig. 7. Load-deflection curve for the bottom prestressed beams (P16 series).

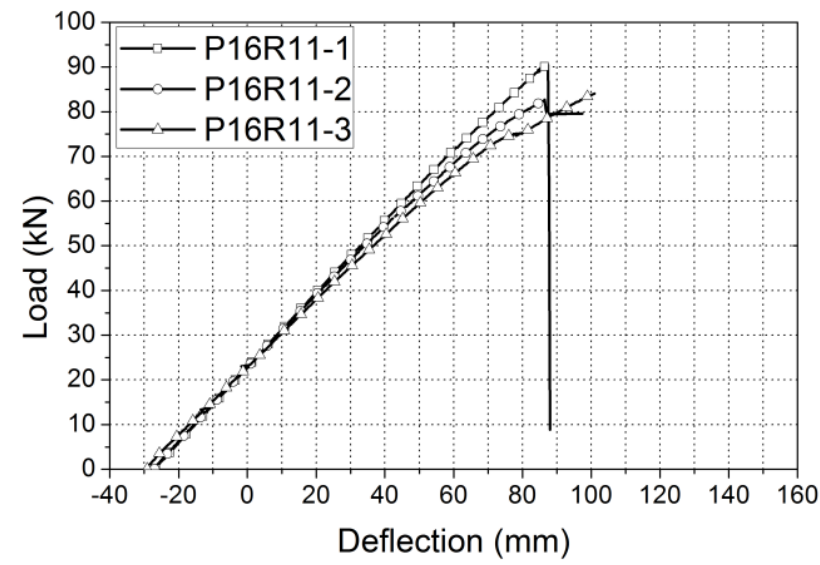

Fig. 8. Load-deflection curve for the bottom prestressed \& top reinforced beams (P16R11 series). 


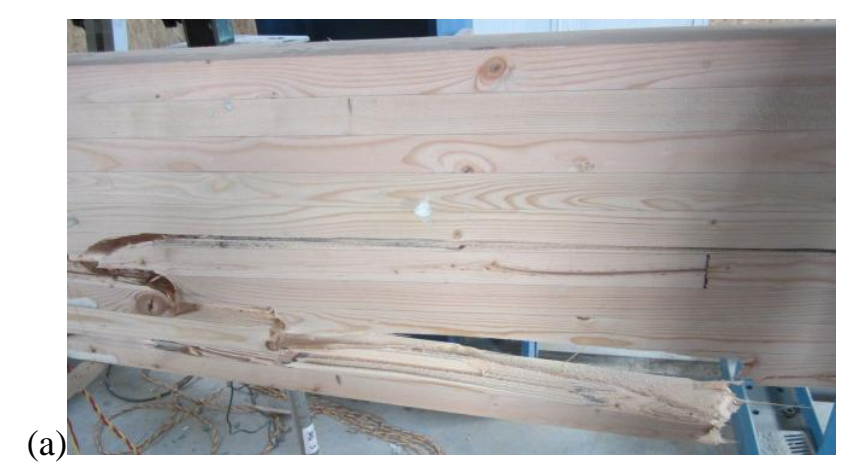

(b)

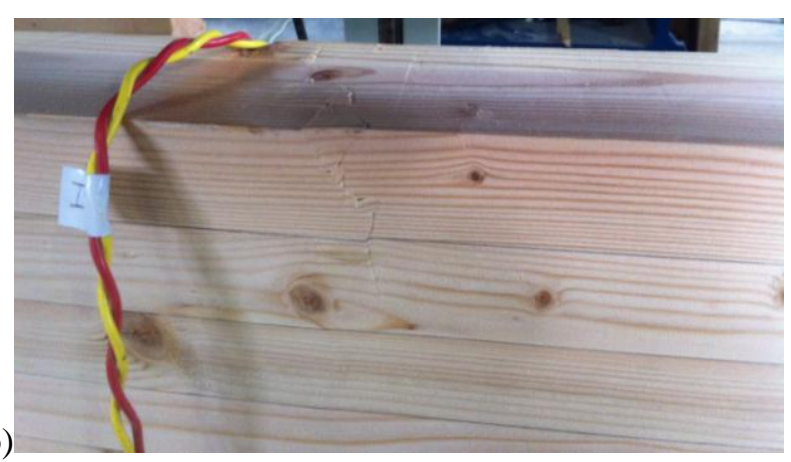

(c)

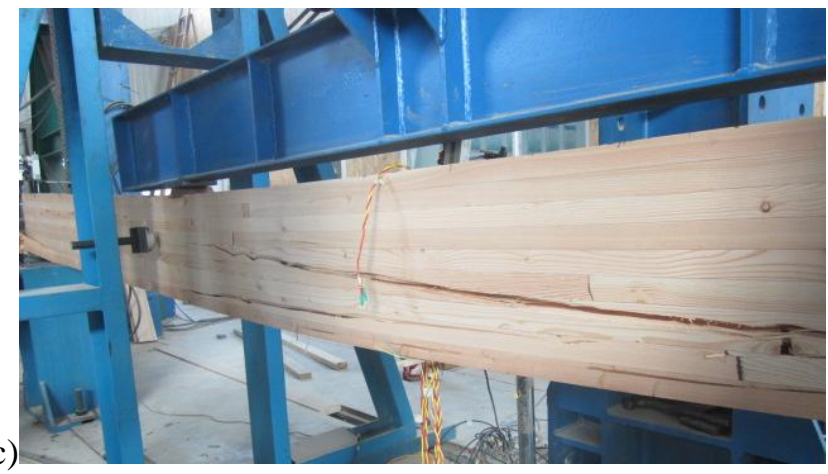

Fig. 9. Typical failure modes of the beams: (a) tension failure, (b) compression failure and (c) flexure-shear failure.

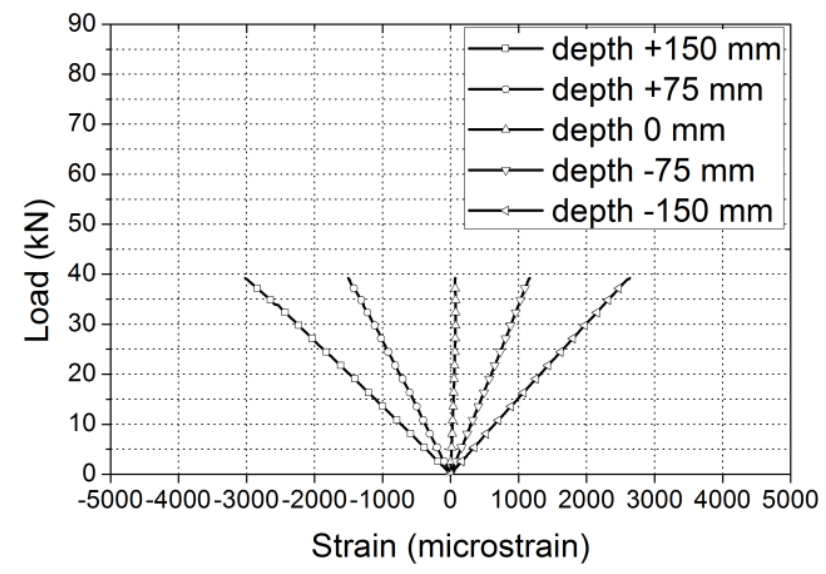

Fig. 10. Typical load-strain curve for an unreinforced control beam (C-3). 


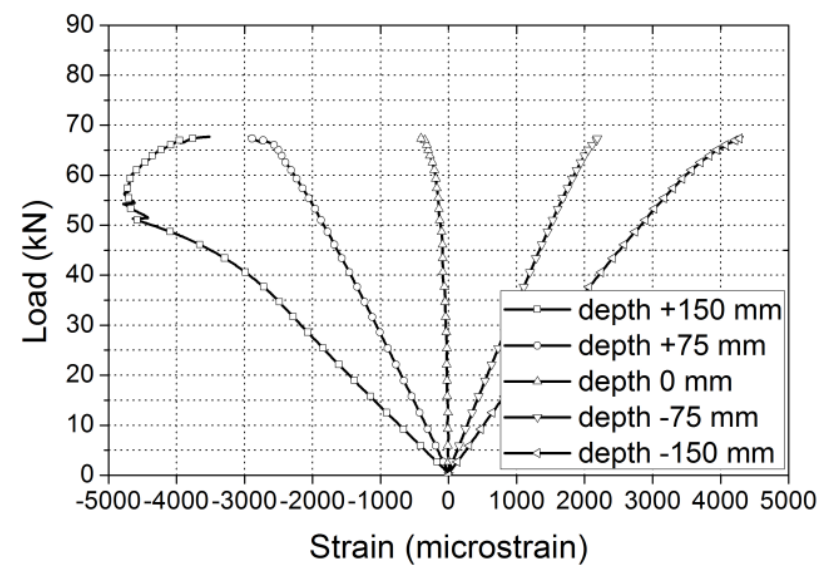

Fig. 11. Typical load-strain curve for a bottom reinforced beam (R11-3).

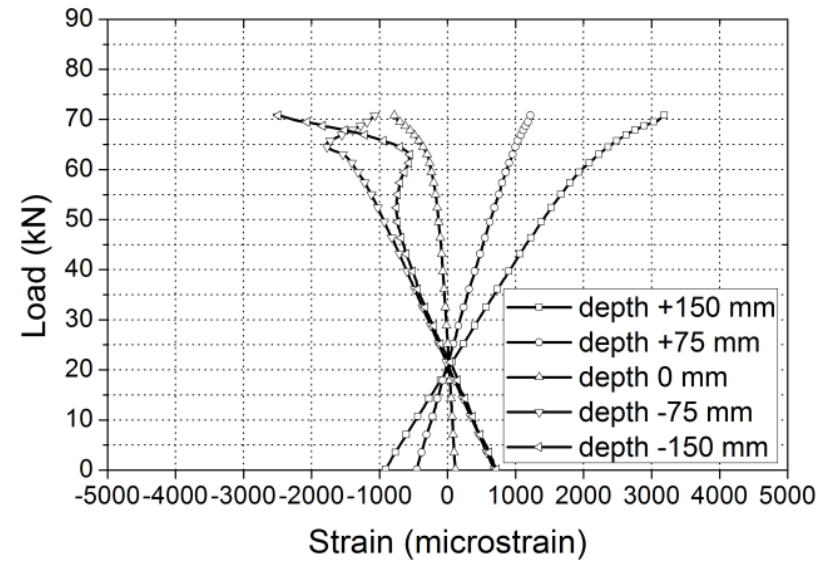

Fig. 12. Typical load-strain curve for a bottom prestressed beam (P16-2).

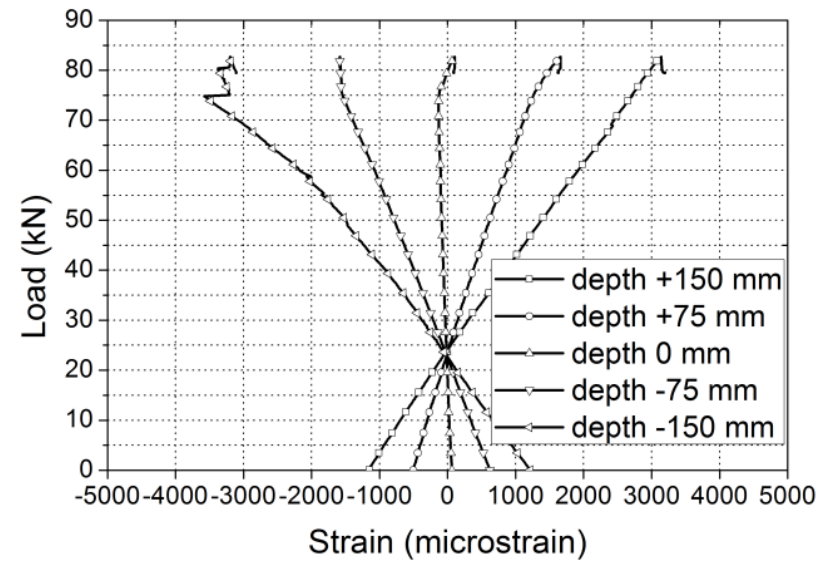

Fig. 13. Typical load-strain curve for a bottom prestressed \& top reinforced beam (P16R11-2). 


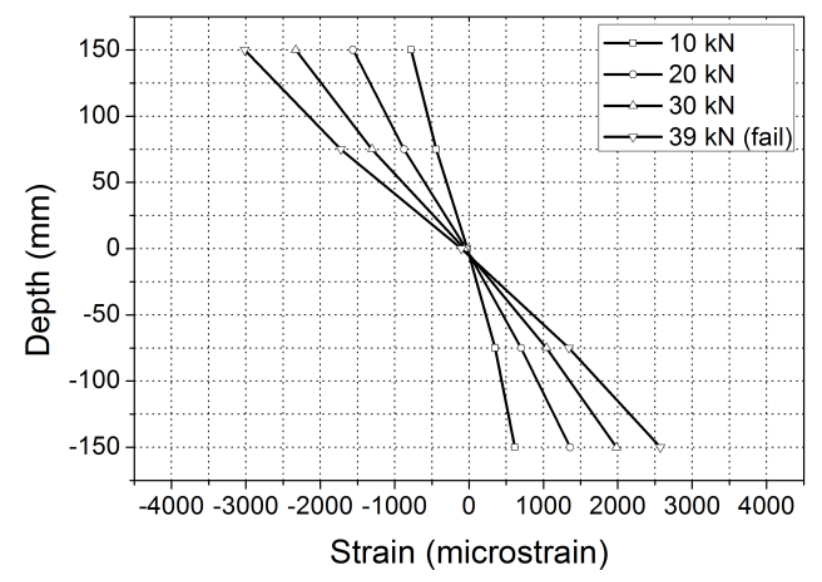

Fig. 14. Typical strain profile for an unreinforced control beam (C-3).

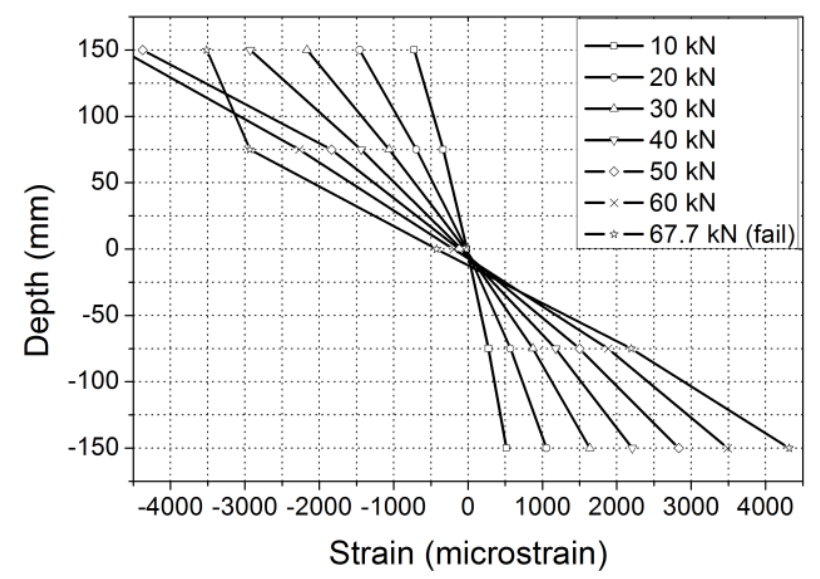

Fig. 15. Typical strain profile for a bottom reinforced beam (R11-3).

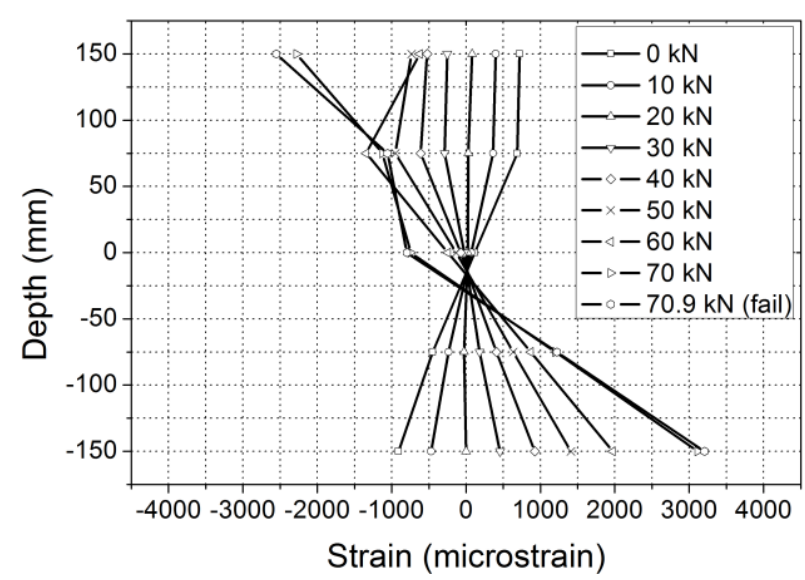

Fig. 16. Typical strain profile for a bottom prestressed beam (P16-2). 


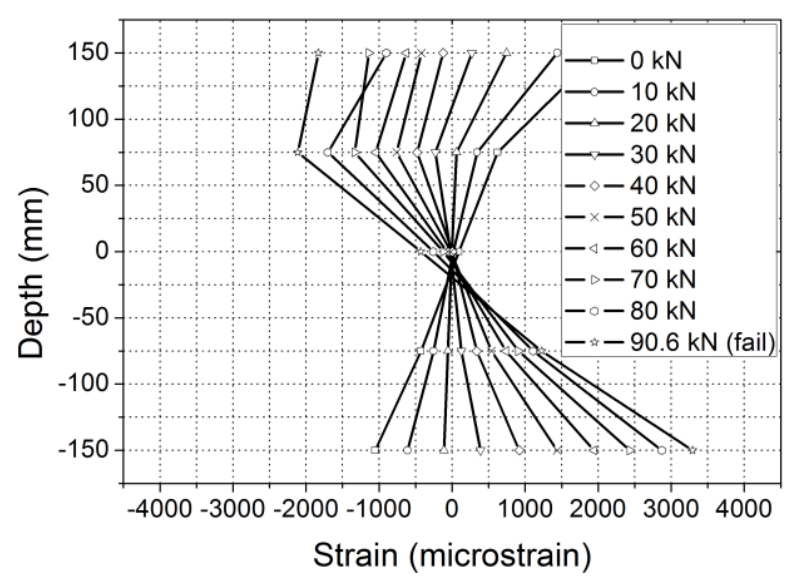

Fig. 17. Typical strain profile for a bottom prestressed \& top reinforced beam (P16R11-3).

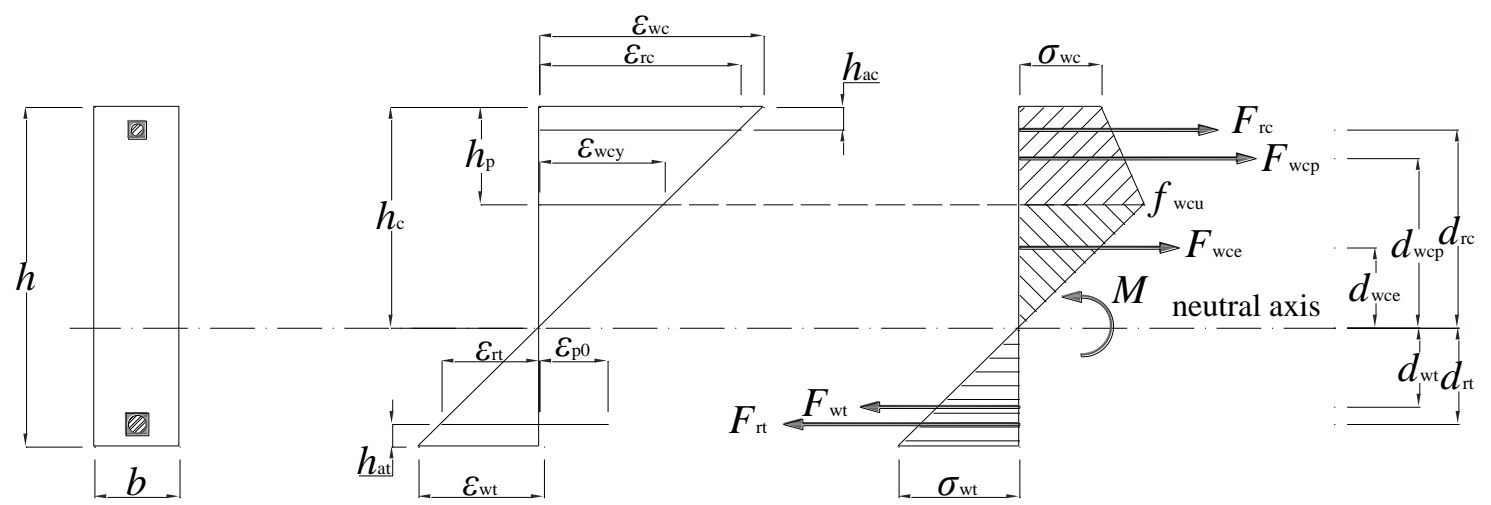

Fig. 18. Cross section of the glulam beam with the notation of the theoretical model.

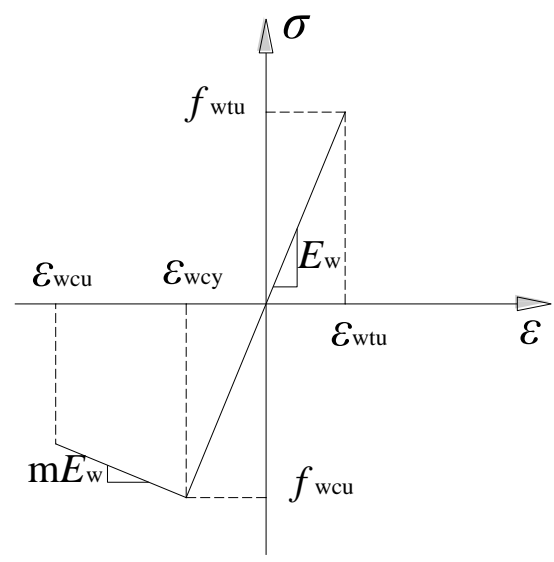

Fig. 19. Stress-strain relationship for glulam. 


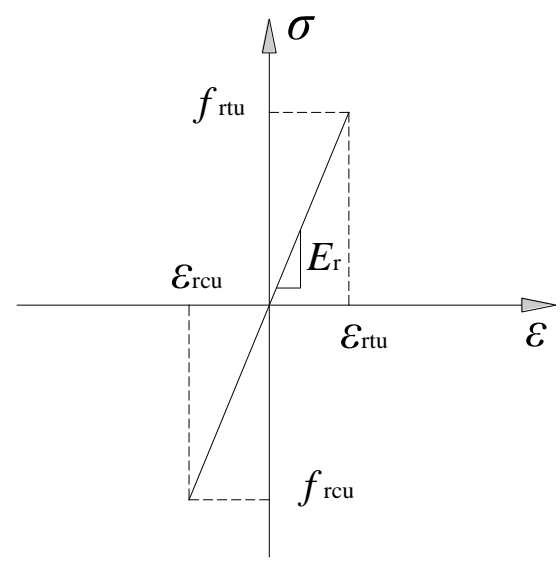

Fig. 20. Stress-strain relationship for CFRP bar.

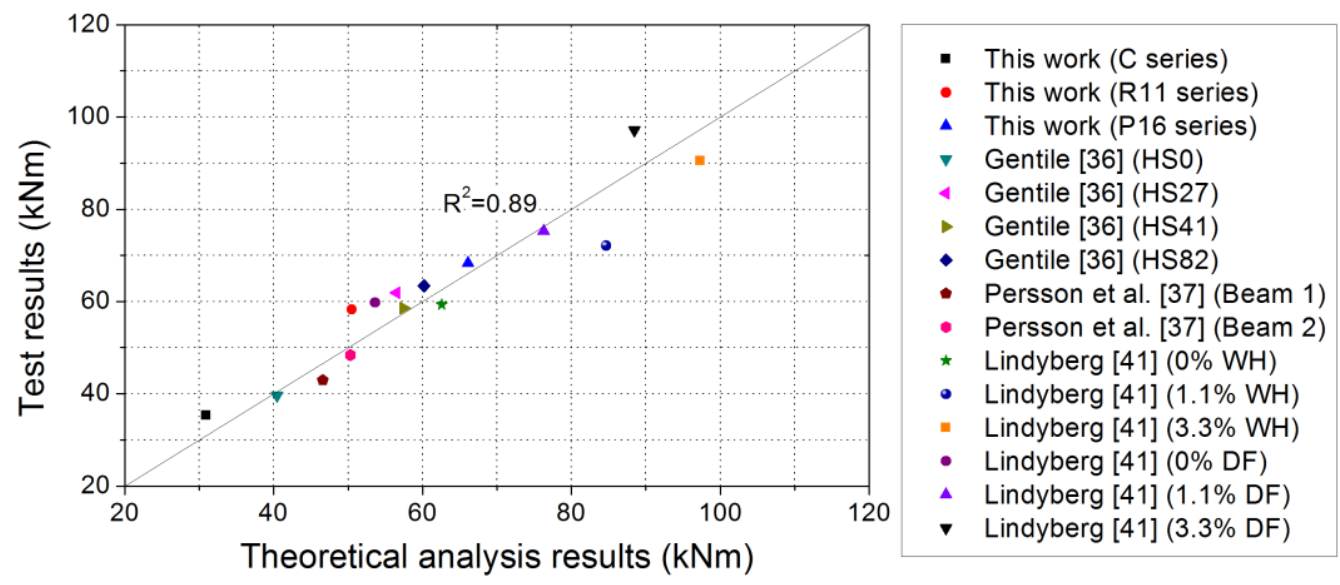

Fig. 21. Correlation of the calculated and experimental values of flexural capacity 